University of Louisville

ThinkIR: The University of Louisville's Institutional Repository

Electronic Theses and Dissertations

1939

\title{
The origin and history of the Louisville and Portland Canal.
}

Leslie S. Wright 1913-1997

University of Louisville

Follow this and additional works at: https://ir.library.louisville.edu/etd

Part of the United States History Commons

\section{Recommended Citation}

Wright, Leslie S. 1913-1997, "The origin and history of the Louisville and Portland Canal." (1939).

Electronic Theses and Dissertations. Paper 1930.

https://doi.org/10.18297/etd/1930

This Master's Thesis is brought to you for free and open access by ThinkIR: The University of Louisville's Institutional Repository. It has been accepted for inclusion in Electronic Theses and Dissertations by an authorized administrator of ThinkIR: The University of Louisville's Institutional Repository. This title appears here courtesy of the author, who has retained all other copyrights. For more information, please contact thinkir@louisville.edu. 


\title{
Unireraity of Iouigville
}

\section{THE ORIGIN AITD HISTORY OF THE LOUISVILLE AND PORTLAND CANAI}

\author{
A Diseortation \\ submitted to the Fooulty \\ of the Graduate Sohool of the University of Louisville \\ In Partial Fulfillmont of the \\ Requiremente for the Degree \\ of vester of Arte
}

Department of History

By

Leglie s. Wright

1939 
Irame of Student:

Title of Thesis: THE ORIGIN AND HISTORY OF THE IOUISVILLE AND PORTIAAND CANAI

Hame of Direotor:

Approved by a reading committee composed of the following mombere:

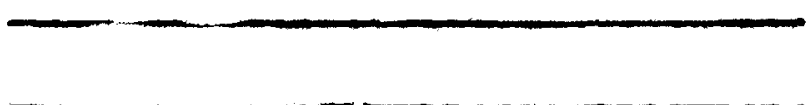

Representative of the Inglish Depertment:

Date: $q-30-q q$ 
o)

$m$

छे

$\infty$

IHE ORIGIN AND HISTORY OF THE IOUISVIITE

AND PORTIAND CATAT

$5087 \%$ 

TABLE OF CONTENTS

Ohapter

I

II

III

IV

$\mathbf{v}$
T1tae

page

Earliest attempts to build a

1

canal at the fallo of the

ohio, and the necessity for

so doing.

From the Incorporation of the Iouleville and Portland Canal Company, and the commencement of work in 1826, to Jenuary 1 , 1848, when operations were commenoed under the amended charter of 1842 .

From January 1,1842 , to Jenuary 31,1855 , when the purchase of the individual stock lexcept the five sharea retained by the members of the board) was completed.

From January, 1855, when the 59

United States acquired control of all but five shares of stock in the canal, to 1868 , when Congress ordered a new eurvey and report to be made on the narigation at the falls of the ohio.

Prom March, 1867, when a joint resolution of the Congress of the United strtes provided for a survey of the Feils of the Ohio, to Julg 1, 1880, when the Louisvilie and Portland Canal was made toll free by the Congress of the United stater. 
Chapter

VI

B1bliography
Titlo

From 1880 when the canel was made free of tolls, to the present. Including a brief description of the HydroElectric Plant.

\section{Plate I}

showing the original condition of the Louisville and Portland Canal.

\section{Plate II}

showing the condition of the canal when the United States assumed control.

\section{Plate III}

Showing improvements completed in 1878 .

\section{Plate IV}

An air view of the Ohio River showing the present condition of the canel. 


\section{CHAPTER I}

Barliost attempts to build a canal at the falls of the Oh10, and the necessity for so doing. 


\section{CHAPTBR I}

Barliest attempts to build a canal at the falls of the ohio, and the neoessity for so dolng.

Hear Lonistille, the Ohio River falle from twenty-8even to twenty-eight feet within a distance of two miles. These rapids early became known as the "Falls of the Ohio." They impeded traffic so much thet boats could safely descend only during periods of high water while it was poseible to make the ascent during even shorter periods of the jear and at greater per1l.

The promoters of Vestern and Southern trade realized that they mast circumscribe the series of rapids, or falls, at Ioulaville, in order to open the Ohio to the free circulation of commerce. Inderlying the entire width of the river at the Falla City is an irregular mass of limestone, forming a series of rapids, pools and falle. Nlthough open channel work was commenced more than half a century earlier In the northern or Indiana channel, the radical and permanent measures taken to open the navigetion of the Ohio consisted in the building of the oanel around the obstructions at the Falls C1ty. 
In the hope of making the river navigable at all times by moans of such a canel, the Iegislature of Eentucky incorporated the Ohio Canal Company in 1804. The sct designated serenteon cities of the etete in which books wore to be opened for abscription. for tock, and named the men who were to be in charge of the salea. The capital stook was to be $\$ 50,000$, divided into 1,000 shares of $\$ 50$ each, though if this stook should be insufficient, the directors might from time to time inorease the number of shares. The works and canal with all their profit ohould be forever exempt from any tax or assesement. The subscribers were to receive returns on their investment by way of tolls. which were levied according to the gize of the boat. Those not exceeding fourteen feot in width and fortyfire leot in length were to pay \$4.00; those not orer fourteen feot wide and ixty leet long, $\$ 5.00$, etc. Boats loaded with coal, lime, iron or other ore, or household furniture were to pay not more then threefourths of the regular tolls. The canal had to be capable of navigation, except in dry seasons, for rosselo and refts, drawing four feot of water, at the least. It had to be begun within three yeare and 
complotod by January 1, 1818. A lottery was authorized whereby the company might raise as much 2a \$15,000 for the construction of the oenal. ${ }^{1}$

The preamble of the law of 1804 stated that there were many people who wished to invest large sume in the canal, but only a portion of the money was subsoribed. 2 It is also true, as was brought out in the Iegislature, that the act was "defective in many of its important provisions." ${ }^{3}$ In an attempt to correct these defects and render encouragement to the enterprise, the Iegislature, in 1805, modified the act of the previous year. The capital stook was now to cons18t of 10,000 sheres at $\$ 50$ oach. The state of Kentucky was to purchase 1,000 shares and reserve for her disposition 1,000 other shares. The United states might subsoribe for shares to the par value of $\$ 60,000$; Penneglvania and Virginia, each, to the ralue of \$30,000; Naryland, Item York, and Ohio, each, to the value of $\$ 20,000$, these states being most directly concerned with the improved navigation of the Ohio.

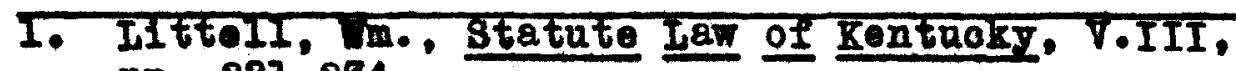
pp. 221-234.

2. Collins, Ieris, History of Kentucky, V. I, p. 551. 8. Eontuoky statute日, 1806, p. I. 
Again the cangl and works were to be tax exempt. It had to be navigable for reseels drawing not over three feet in time of low water, and mast bo twentyfour leot wide at the bottom. I lottery was again authorized with the privilege of raising a sum not oxceeding $\$ 30,000$. Work had to be began within three years and oompleted by Januery 1, 1815. Tolls were levied acoording to tonnage for shipg and ses ressels, and according to sise for other boats. ${ }^{1}$ After the act passed by the Legislature of Kentucky, to incorporate the Ohio Canal Company. some competition arose, and the preominence of the opposite side of the river as a proposed site wa urged. In reply to this, Nr. Jared Brooks, an engineer employed by the yanagers of the Canal Company, says in his report:

It has been idly reported by some, who are unfriendly to the interests of the Ohio canal company, that the ground on the side of Kentucky 18 too low--.-was that eren the case, agreeable to the section, there is higher ground immodiately on each side of it, and any height may be chosen to fifty feet, without rarying materially the course or distance. It the foot of the cansl, the bank of the river is upwards of forty feot high from low water, and immediately on each side moch higher. That part of

1. Kentuck Statrtes, 1805, pp. 1-18 
Shippingport towards the proposed canal, 1s fifty feet high. The bank is uniformly of otrong clay, which forms a bold and permanent shore, and which is washed by the mein channel of the ohio: so that boats and vessels may lay along side, and unlade into the mills, warehouses and manufactories when established, and receive lading therefrom, with the greatest imaginable convenience.

It cannot be denied, that approach to the head of a canal on the south side, will be more safe and easy, than on the north side---nthat the length and depth will be less, by more than one-third---that the approach to the foot will be more easy, by the difference of asconding a considerable distance, and crosing the ohio in a rapid current--and that it will enswer every desired purpose when completed, more effectually, than a canal on the north side can be possibly made to do.

In fact nature has arranged the ground so perfectly appropriate for the grand purpose of a canal on the south side, that considering the facility with which it may be effected, and the immense advantage to the whole western country, of the water works that may be thereto applied, it may be acknowledged, that she has made ample amends, for the trouble caused by the obstructions thrown in the way of navigation at the rapids.

Should any be disposed to doubt the accuracy of so favorable a description of this ground, the shafts are secured, and left open for the inspection of those who may please to examine, during which time the face of the ground will show itself.

Previous 1 to to my applying instruments, to ascertain precisely the condition of this ground, I traversed and examined it thoroughly on both sidea of the ohio, and used every endeavour to discover some ground for reports in favor of the north side; but the great length and forbidding aspect of the country, through which a canal should 
necessarily be carried, and the danger and difficulty of approach with boats, to the places where the head and foot of canal should be, fully evinced to me of (sic) the utter impracticability of effecting 1t, unt1l many jears hed elapsed, and brought into existenoe far more, and greater oncouragement for public enterprise, than are at present connected with that point: even admitting there to be no other more practicable route for a canal. So many powerful obstacles, to the undertaking to complete a canal nevigation on the north side, present themeelves to the mind in rapid succession, that they appear Ineurmountable, and baffle all correct oaloulationa of the expense of money and time necessary to the undertaking,...-therefore, to the preeminence of the side of Kentucky. all oompetition must jield, however mighty may be the struggle of speculation. 1

The contemplated Company of 1806 was glow in organizing, and very little headway was made for some time in doing angthing definito. The project was nrather stupendous," and naturalig caused some hesitency. The Associates, therefore, memoralized congress on the subject, arking for ald. The committee of the Senate, to whon the memorials were referred, reported that all its members had personeliy visited the site, that they believed in the practicability of the undertaking. that thoy were mindful "of its vast benefit and importance to our whole western country, erpecially to that part of 1 t which is connected with the western weters, and that it must

1. Proceedings of the Managers of the Ohio Canel companr, $1805, \overline{p .6}$. 
nocessarily onhance the value, and greatly increase the sale of public lands." "I They therefore, had no hesitancy in recommending to Congress the granting of elther of the terms asked for; but until the company was fully organized, they believed it unwise "to offer any specific proposition on the subject."

The committeo of the United States House of Representatives to whom was referred the memorial of the Kentucky Legislature made 1 ts report on yarch 19, 1806. It declared in part that.

of the immense importance of the proposed oanal no one can doubt for a moment who has considered the vast extent of fertile territory which ia watered by the ohio and its tributary atream, and the incalculable amount of produce which must, of course, find its wey to market by descending that river and oncountering the dangers and difficulties of passing its rapide. But. besides the general advantage which would result from the completion of the proposed canel, it is, in the opinion of the committeo, particularly interesting to the United States. Inasmuch as it would greatly enhance the ralue of the public lands northwest of the ohio. There can be but little doubt, but thet by the additional value it would give to the public lands, the United States would be more than remunereted for the ald which the Legielature of Kentucky hare solioited.?

The report further stated that the committeo would not hesitate to recommend a subsoription of shares

1. American State paperg, V.ZQ, part I, p. 419.

2. Ibla., pp. 453-45\%. 
if they beliered the state of public finanoes was such as to justify 1t. But the revenue of the united state wer alroady pledged to purposes, though not more useful, jet more urgent. Hence the aid sought was denied. The comitteo of the United Stater Senate to whom was referred the Kentucky documents on the oanel. handed in 1ts report on January 24,1807 . It admitted that

the national importance of the canal is undeniable. The immense country of the ohio and its waters above the rapide, in seeking a market for its surplus produots, has to oncounter the obstruction in the narigation of that atream. This obstruction, never entirely free from danger, is such 28 to absolutely preclade the passage of vessels for sereral months in the year in their descent, and, when laden, for the whole year in the ascent of the river. The rapidity of the current (which arerages at the rate of from ten to eleven miles through the falls), leaves no alternative for a safe royage up as well as down the river but in a oanal. 1

For the next few years, things were at more or less of a standatill except for the fact that the neceseity of a canal was becoming more apparent as the inoreasing river trade found itself facod with an ever preaent barrier at the falls of the ohio.

1. Amorican State Paperg, V.xa, Part I, p. 4/9. 
In January, 1818, the Legielature of

Kentucky created the Kentucky-Ohio Canal Company, with a cepital stock of $\$ 600,000$, dirided into 6000 ehares of 100 each, 2,500 of which were reserved, 600 each for Kentucky, Ohio. Penneylrania, Virginia and the Federel Government. The Directors were authorized to do as the thought best to obtain subsoriptions. The steamboat first made its appearance on the ohio in 1811. making a deeper canal necessary, so the act prorided for a width of thirty feet at the bottom, and depth of four and a half feet, "sufficlent to carry through the whole distence......eny boat or creft not drawing more than four feet of water." A change was made in the tolls. A loaded llat boat had to pay ten dollars and an empty one six. Steamboats, barges and keel boats were to be charged $\$ 1.50$ per ton if loaded, and half that per ton if empty. partially loaded boate were to pay in proportion, and the geveral raten were to be doubled for veseels ascending the river. To induce oepital to enter into this undertaking, the law provided that if the difidends were lese than twolve and a half per cent after two years of canal operation, the directors might raise the tolls, and if over eighteen 
per cont, the Iegislature reserved the right to reduce them so that the specified income should not bo excoeded. This act did not provide for tax exemption. 1 Two more jears elapsed and nothing wae acoompliahed. 2 The amended act of 1820 authorized the oompany to organize when $\$ 100,000$ of stock had been oubscribed, and reserved stock for various states and the United States, and again contained the proviaions relative to dividends, 3 but the public spirit was too 10w or capital too insufficient or too sensitive. 4 on December 1, 1824, Governor Deshe presented h1s annual message to the Legislature, in which he urged the oonatruction of internal improvemente. Kentucky, because of her inland position, must remain an exporting state, and ony impediment in her path to the ooean muat necesearily obstruct her progrese to wealth and power. The Governor pointed to the works of other atates and urged that Kentucky construot her own internal improvemente. Hot ell could be undertaken at once, so he preferred that the canel be pushed through, and that the profits arising from it be nsed to construct other means of

\footnotetext{
1. Tentuck Statutes, 18I/-1818, pp. 419-425.

2. Collins, Ienis, op. cit., V.I, p. 562

3. Kentroky statutes, 1819-1820, pp. 911-914.

4. COIIIn,. IONIB, Op. c1.te, V.I, p. 552 .
} 
transportation. It was customary then to collect tolls from turnpikes as well as from canals, so the Gorernor contended that when the whole system of Improvomonts should "be completed, the profits, it is bellered, would noarly or entirely relieve the people from the burthen of taxation, and not only support the government, but also build up and maintein many liberal institutions."l

other atates were interested in this canal. Gorernor Lorrow of Ohlo sent to Deshe an account of the action of the Iegislature of his state and series of documents relative to the canal. Darid s. Bater, a civil engineer of ohio, had estimatod that a canal forty-four feet wide at the bottom and fifty-six feet wide at the top and four feet at lowest water, could be constructed on the Kentucky aide at a cost of $\$ 306,014,68$, and on the Indiena side for $\$ 533,048.2$

The most clearly expressed reasone for canal were given by Alfred Kelly, Aoting Commiseloner of the Lake Erlo and Ohio Canal:

It may be assumed as a fact, that more damage is annually sustained by the conntry

1. Senate Journe1 (Tentuck ), 1824, pp. 9-10. 2. Ib1d.. Dp. 193-198. 
situated on the Ohio, and its branches abore the Falls, in consequence of that obstruction, than the whole amount required to provide a complete and permanent remedy for the ovil. The actual expense inourred in the transportation of property around the Falls, forms but a small item in this account. The damage sustained in consequence of the delays ocosaloned by this obstruction, in convejing to market the surplus products of the upper country, is one of much greater magnitude. The market at 110 orlean 18 so fluctuating that the delay of a fow days often oosesions a serious diminution in the price obtained for a cargo of proviaions. The climate and situation are such, that the investmont of - large surpans capital in that place applicable to the exigencies of commerce, can noter bo reasonably expected. The market is therefore liable to be orerstocked and a regular demand for a time destrojed. Provisions, if long exposed on their journey down the river, or in the warehouses at INOW Orleans, to the hoat and moisture of that climate, are subject to be damaged and consequently diminishod in ralue, and injured in their general reputation in foreign markete.

Obstruction of the "palls," argued Kelly, prevents goods being pleced on the Hew Orleans market when the prices are highest. When the "Fallo can be desconded with safoty, a vast amount of property is thrown at once into a market which....1: limited in extent and fluctuating in price. Mlthough the arerage price of flour in New Orleans, is 25 or 30 per cent less than in the sea ports of the stlentic states, yet it frequently oocurs that Few Orleans is supplied 
With that article for home consumption from those very ports." This illustrates the inoquality of price in the market.

To further prove the need of a canal, $\mathbf{M r}$.

Kolly wrote:

wach the largest proportion (of the surplas of the upper country) still descends the ohio and Masiseippi in flat boats, al though navigated by a large amount of steamboat tonnage. This is owing in a great measure to the obstruction of the Palls to steamboat narigation. This rapid can bo passed by steamboats, especially in asconding, during a small part of the year. Proviaions from above the Fall. are on an average fifteen days longer in reaching their destination, "and much more subject to being injured by exposate to the weather and other accidents, when transported in flat boats, than when shipped in stean boata." on this account many persone prefer cending their flour, pork and other provision. to market on board of steamboats, ovon at the present prices of erelight cherged by these boats, whioh on flour is now about one dollar per barrel from Cinolnnati to Her Orleans.

Should the canal be constructed, it was

believed that freight on flour would be reduced imediately to fifty cents per barrel, which "effect would be the resalt of the more constant employment obtained by those boats, the greater safety and less delay in narigating the river, as well as from the reduction in the actual expense now incurred in passing the palls and carrging 
the oargo acrose the portage at that place." Kelly maintained thet flour could be transported best by steamboata. To atrengthen his claim he declared thet

300,000 barrels annually descend the Falls, Which estimate is probably below the truth; the sum of 150,000 dollars on the freight of this article alone, would annually be eaved to the upper country. But it is beliered that the 1088 sustained by delay, actual 1085 and damage recoired by the property, its bad repatation on the market, the extra expense of transportation. and the sacrifice necessarily made in an orerstocked market, in consequence of the obstruction at the Falls and the mothod of conveying property which it induces, is altogether equal to one dollar on each barrel of flour.

Flour constituted about one-fourth of the value of the products of the upper country which descended the Falls, according to Kelly, so it was reasonable to estimate nat least an equal amount of 1088 on all the other articles, which together form a sum three times as great." sccording to Commissioner Kelly, about fire thousand flatboate were supposed to have desconded the Kississippl and arrived at Iew Orleans annually. Of these boats he estimated that more then three thousand annually descended the Fall. of the Ohio. Although the records of the company for the first ten years after the opening of the canal show 
that in only one year ald the number of flat and keel boats combined, golng through the canal, total 88 high as 710, nevertheless, Mr. Kelly' estimato seoms reasonable when considered in the light of the fact that during at least three or four monthe of the jear the water was high enough to permit all types of boats to go over the Falls, and that oren during extremely low water, many flatboat could safely navigate the rapide in descending the river. From the construotion of these boats, they could never be used in asconding navigation. So they were sole at a 1088 of $\$ 80$ each, on the arerage, which made a 108s by the apper country of $\$ 240,000$ aear. yoreover, 1t required a larger number of hands on flatboate than on steam boats in proportion to the amount of freight. These hands were obliged to return by steamboat, being anemployed on the home trip. This entalled expense:

The damage sustained by property convejed on board these badiy constructed ressels, the loss and risk incurred, and the exposure of holith and life, occasioned by this thod of transportation, together with the bad appearance and lor reputation of proviaions, mat all be taken into account when forming on opinion of the relative advantages attending the two mothods of conveyance. 1

1. Senate Journal (Kentuckr), 1824, pp. 199-201. 
Thus we seo thet the first twenty-fire Jears of the nineteenth century were taken ap with efforts which although not crowned with success, were nevertheless instrumental in seouring canal around the "Falls of the ohio." It remained for the aecond quarter of the century to see the work eotually began and comploted. 


\section{CHAPTER II}

From the Incorporation of the Iouisville and Portland Canal Company, and the commencement of rork in 1826, to Januery 1 , 1842, when operatione were commenced under the amended charter of 1842 . 


\section{CHAPTER II}

From the Incorporation of the Iouls 1110 and Portlend Canal Company, and the oommencement of work in 1826, to Jenuery 1 , 1842, when operations were commenced under the amended charter of 1842 .

By the time the flret quarter of the nineteonth contury had come to olose, the public demand for canal was urgent, so by an act approved January 12, 1825, "Hioholas Berthoud, others, and James Guthrie, with their associates," were incorporated by the legislature of Kentucky as "The Louisville and Portland Canal Company"; they and their successors were to have perpetual succession. The capital stock of the company was declared to be $\$ 600,000$, which was divided into 6,000 shares of $\$ 100$ each. The company thus created was to construot canal navigation around the falls of the ohio, with sultable locks, docks, and basins, within the state of Kentucky. $\triangle$ president and four director of the company were to be elected annually; the president and two of the directors to constitute a quoram. The rates of toll authorized for the passage of vessels, etc., through the canal, were: on steam and keel-boats, twenty cents per ton; on each llat boat, four dollers for every 
sixty feet length, not excoeding twonty feet width; pajable in gold or silver ooin. It was made obligatory upon the compang to keep a true account of costs and expenditures, and annually to declare and pay dividends. They were required to moke an annual report to the legislature of Kentucky.

A sliaing seale of tolls was authorized, by which the profite to be divided should be kept up to at least twelre and one-half per cent "on the capital expended," but in no erent should exceed eighteen per cont.

Other usuel and necessary powers were conforred upon the company, and the canal was to be completed in three years.

4 sectional spirit was manifested in the passage of this act. It passed the senate on July 11 , by a rote of 25 to 7 , but every one of the opposing members represented counties lying in the southesstern pert of the state, which would benefit the least by the canal. 1

An attempt was made to include a rider to the b111, to wit:

1. Senate Jonrnal (Kentuck ), 1824-25, p. 432. 
Be it further enacted. That the legislatire hereby retain the right of purchasing said canal, by paying the cost thereof, together with ten per centum per annum thereon until paid: Provided, the election of the Commonworlth to purchase said canal, be made within two years from and after the passage of this act. 1

However, this measure was defeated by a vote of 26 to 6.

In his annual message to the legislature,

in November, 1825, Governor Desha said that,
An official notification has been recoired by me from the President of the Iouieville and Portland Canal Company, by which it appears that the whole oapital stock of that company has been subscribed for, and that such measures have been taken as will ensure the completion of the canal within the time ilmited in the charter. It may therefore be fairly presumed, that this important work. so long desired by the oitizens of our own and other states, will be achieved by the company incorporated at the last session of the General ssembly.2

Although the law incorporating the canal

company did not reserve any stock for the United States, jet an investment was sought from that quarter. In April, 1826, the United States Senate had under discuseion a bill providing that the United Statea

1. Senate Journal (Yentuokg), 1824-25, p. 432.

2. Ibld., I825, p. I6. 
purchase 1,000 shares of stook so long as the stock should not be over $\$ 100$ per share. Johnson and Rowen of Kentucky, and Ruggles of Ohio argued for the measure on the ground that it was an opportunity for the United Stetes to invest money with benefit to the Ireasury, holding that it was bellered to bo the best investment in the country. Chandler of raine and Van Buren of Her York opposed the bill on principle. It passed the upper house by a rote of 22 to 16. Hugh I. White oset the only negative vote from the West. This bill passed the House and was approved by Prosident sams on Hay 18, 1826.

Governor Desha again spoke of the canal in his annual mesagge to the legislature in December, 1826, when ho said:

It must be subject of perpetual regret to every patriotic mind that the state did not, with her own resources, undertake the construction of the conal at Iouforille. It would have been an imperishable fund; a source of rerenue as lasting as the ohio river 1tgelf, which would have enebled the government to accomplish the most extensive and useful plens, without increasing the burdens of the people.1

The second annual report of the canal company

1. Sonate Journal (Kentucky), 1826, p. 14. 
to the legislature, for the year 1826, made mention of the fact thet Congress had authorized a subscription of stock. The certificate was issued, and the several installments peid.

The first installment of $\$ 10$ on all shares was called for on December 26, 1825, payable on the fifteenth of March following. On the fourth of April the second installment of $\$ 10$ on each share was called for, payable on the twentieth of June; and on the twelfth of August the third installment was called for of the same amount, payable on the first of November, and notice was then given that all shares, on which this, with all previous installments, should not be paid on that day, would be forfeited to the company.

The amount received on the stock is as follows, Viz: on 1,630 hares, which under the foregoing notice have been forfeited to the company---one dollar only according to the terms of the original subscription having been paid on each 10 . . . . . . . . \$ $1,630.00$ Ten shares on which twenty doliars had been peid, belonging to the estate of a decersed person, on which administration had not been taken in time to make the payment of the third installment. . 4,360 shares on which thirty dollers have been paid on each, being the full amount of the installments called. . $130,800.00$ 6,000 shares.......... $\$ 132,630.00$ 
By the Treasurer's account, it will be seen that he has paid the orders of the board, amounting to $\$ 84,616.14$, and there 18 now in deposit in the Iouistilie branch of the United States Bank, to the credit of the Iouisvilie and Portland Canal Company, the sum of $\$ 48,014.86$, which makes a total of $\$ 132,630.00$, and belances with the above amount taken in for stock. 1

The board took no steps to dispose of the 1,630 shares of forfelted stock, deeming the amount of stock still out, whon fully paid up, as sufficient to complete the canal.

The contractors were prevented from boginning work in March, 1826, due to an unusually large freshet. On the receding of the water they commenced the excavation of the earth, but with a force too small to be satisfactory to the board. By the last of September, howerer, the force amounted to one thousand and sixty-two men, from which it decreased by December 30, to s1x hundred and ten men. Notwithstanding the difficulties that the contractors labored under in procuring men," about

1. Senate Journal (Kentuck7), 1826, pp. 204-206. The annual reports of the President and Directors of the Ioulsvilie and Portland Canal Company are found in the Senate Journal for each jear, and will henceforth be noted as above.) 
one-sixth of the originally estimated work was comple ted.

Water limo of the best kind for cement was found in the lower lockpit, forming one of the strata of rock excerated.

As a general result the board stated that, "no material difficulty or obstacle has presented 1tself, and an obundant supply of materials are, and can be easily obtained--.-the men employed on thie canal have onjoyed as good health, as any equal number of laborers in any part of the Jnion----and we are assured by the contractors, that if the approaching season should be farorable, the work will be completed within the time limited in the contract. "l

The report of the canal company for the year 1827 stated, in addition to listing the varions recelpts and disbursoments, that the three installments on the stock of the company called for during the year were punctually paid. The salary paid to Chiel Engineer Bates had been 1ncreased by $\$ 1,000$, making it total $\$ 2,800$ per jear. Wr. Edward Shippen still held the office of President of the Board of the company, having been eleoted thereto under the original charter.

1. Senate Journal (Kentucky), 1826, p. 206. 
Several alterations suggested by the ongineer in the original plans, made it possible that a larger oum would be required for the completion of the work than was previously expected, hence the board determined to dispose of the forfolted shares of stock, when they should be applied for. Such application was made, and 300 shares were sold, making the total number disposed of 4,670, and leaving 1,330 in the hands of the company.

Unprecedented weather conditions, plus a difficulty in securing labor prevented the work approaching its inal termination in the degreo anticlpated in the last annual report. However, the contractors assured the board that such measures had been adopted as would enable thom to complete the work during the next season, unless prevented by some unforeseen misfortune.

In order to enable the stockholders to form an estimate of the present and probable future importance of the canal, the following abstract was attached to the annuel report, showing the arrirals of steam boats at shippingport, with the amount of their tonnage, during the past three years, exhibiting 
an increase of the commerce of the ohio, equal, if not superior to the most sanguine caloulations that were made previous to the commencement of the canal.

"Abstract of arrivals at shippingport from below, during the year 1827."

\begin{tabular}{|c|c|c|c|c|}
\hline 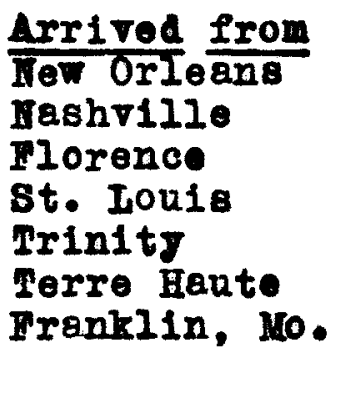 & $\begin{array}{c}\text { Stoam Boats } \\
39 \\
16 \\
8 \\
14 \\
3 \\
8 \\
1\end{array}$ & $\begin{array}{r}\text { Tonnale } \\
8.585 \\
1.847 \\
740 \\
1.880 \\
897 \\
140 \\
225\end{array}$ & $\begin{array}{r}\text { Tr1po } \\
122 \\
33 \\
25 \\
69 \\
13 \\
4 \\
1 \\
264\end{array}$ & $\begin{array}{c}\text { Total Tonnage } \\
31,989 \\
3,518 \\
2,310 \\
8,740 \\
1,047 \\
170 \\
225 \\
17,999\end{array}$ \\
\hline $\begin{array}{ll}\text { Arrivale } 1826 \\
\text { Arrivale } 1825\end{array}$ & $\begin{array}{l}51 \\
42\end{array}$ & $\begin{array}{l}9,388 \\
7,484\end{array}$ & $\begin{array}{l}182 \\
140\end{array}$ & $\begin{array}{l}28,914 \\
24,964\end{array}$ \\
\hline
\end{tabular}

In view of the alterations suggested by the chiof engineer, and the fact that private capital was not flowing into the canel enterprise as repialy a had been expected, in Januery, 1829, Rowan of Kentroky was arging the United States Senate to take more stock, claiming that the work could not be done without the aid of the Government. 2 The stock went below par and many shares were forfeited. The canal was only about two and one-half miles in length, but it had to be cut through solid rock. The work was two-thirds done.

1. Senate Journal (Kentucky), 1827, p. 187.

2. Ib1d., I829, p. I34. 
The purchase of stock was not a question of principlo with Rowan, but one of expedienog. John Branch of forth Carolina asked thet the bill be laid over until the question of the distribution of pablic money had beon settled, oondemning this bill as purely local. ${ }^{1}$ To this proposal, Johnson of Kentroky replied that the canel was of interest to the whole Festern country, that is, to four million people. As to the distribution of Pederal money, this was the only legitimate object for which it could be expended in the West. Johnson of Loulsiane urged immediato passage to prevent obstruction to the project that would soon occur due to the rise of water. The measure passed the senate twontyfour to elghteen, with Hugh I. White of Tennesser again cesting the only dissenting vote of the West. 2 This b111 was approved larch 2, 1829, Just before the close of the Adams' Administration. It provided that the Onited States purchase not over 1,350 sheres at a price not over par, from any stock which might have beon forfeited to the company and not again disposed of. 3 The legislature of Kentucky, on December 12 ,

\footnotetext{
1. The U.S. Treasury Tes showing a surplus each year. 2. Ragister of Debates in Congress. Vol.V, pp. 47-49. 3. Ib1d.. Appendix, p. 66.
} 
1829, anthorized an increase of capital stock from $\$ 600,000$ to $\$ 700,000,1$ and exactly two jears later gave the company blanket authority to extend the copitalization to such an amount as would be suffiolent to pay all the costs of constructing the canal. 2

The oanal was completed and opened to traffic, and the firet boet passed through December 22, 1830. As originally constructed, the canal was $1.9 \mathrm{miles}$ long, 64 feet wide, and had at its lower end a three flight lock with a total lift of 26 foot. Bach ohamber was 198 feot long botween mitre posts, with available length of 185 feet, a width of fifty feet, and a lift of eight and two-thirds leot. The total cost of the work, including the purchase of land, was $\$ 1,019,277.09$.

In 1830 , when the canal was completed, its dimensions were thought to be sufficient for all time, but gradually the size and model of ateam boste were so changed that in 1862 only fifty-seven per cent of the craft in use on the western watere could pase through the 10cks. 3

\footnotetext{
1. Kentucky Statutes, 1829-1830, p. 10

2. I01a.. 1831, p. g6.

3. Report of the Chief of Englneers, U.S. Army, 1878, ippendix $\mathrm{T}, \mathrm{p} \cdot \mathrm{Tr}$.
} 
After the opening of the canel. a

quantity of mad was found to be deposited in the lover lock. The engineer belleved it would be removed by the current passing over it, However, he proved to be mistaken, the obstruction temporarily decreasing by two-thirds the number of boats passing through the canal.

Several imperfections were found in the oanal work during 1 te flrst year open to traffic, which had to bo corrected. Bxcavated rock was placod on the slope wall as an economical arrangement, but proved to be rather a false economy when the action of the frost during the rinter precipitated the stonea into the canal, causing much obstruotion to the pasagge of large boats.

It was found noceseary during the first jear, to widen the entrance to the canal, to aroid the danger of the Bwift current.

During the first thirteen months after 1ts completion, the canal was open to traff10 183 days. In that time 827 boats. Whose tonnage amounted to 76,323 tons, pessed through the canal, and from the number of arrivals and depertures of boats above and 
below the falls, the directors estimated that since the obstructions had been removed, the number of boats thet would pass the canal in each year would be quadruple that of the past; and that upwards of 300,000 tons would pass the canal annually.

An 1dea of the dissetisfaction with the canal which came from some sources can bo seen in the following extract in which it is pointed out by the U. S. Army engineer, that the Government was unjustly profiteering from a natural handicap to commerce, which it should heve been exerting overy effort to remove.

In 1826, the Government for the first time in its history, became a stockholder in a private corporation chartered by a State, and that too, in one whose object was to overcome obstructions to navigation in a national highway.

In a few years after the canal was opened, many complaints were raised against 1t. It was urged as an objection, that it was a monopoly granted to private individuals, in the construction and control of a work which was directly connected with, and, in effect, part of a great "national highway"; that the tolls levied were such as to impose a heavy tax on western commerce, which ought not to be at the mercy of private corporations or individuals.

1. Senate Journal (Kentucky), 1833, pp. 248-850. 
The total amount of tolls collected up to January 1, 1842, or in eleven years, wae greater than the original cost of the work.1

The investment of the Government in the stock of the canal company proved to be quite an asset to the Treasury. In 1830 the United States government was a atockholder to the amount of 2,335 shares, costing $\$ 233,600$. In 1831 the Government received 567 shares more in lieu of dividends. Betwoen 1831 and 1842 it recolved $\$ 257,788$ in cash from the dividends declared by the company; so that at the end of twelve yeare the Gorernment received \$24,278 in oash and 567 shares in stock more than it invested in the canal, and was still the owner of 2,902 shares in the canal, valued at $\$ 290,200$; thas receiving $\$ 547,978$ for its original investmont in the canal. 2

socording to the elghth annual report of the canal company, the winter and spring of 1832 were without parallel in the history of the western country. Narigation was closed by lce for an unusual period, which was followed by reperted floods, one of which was nore than two leet above any flood of which there was 1. Roport of the Chier of Englneers, 1882, Lppendix X,
2. heport of the Chief of Engineers, 1868, Appendix II,
p. 529. 
any tradition."

After the water receded, many repairs Wore made and new machinery added. After re-opening for navigation, the receipt of tolls amounted to about $\$ 1000$ per woek, and at a time when the river was low, so that only small steam boats and flats could navigate it.

The Directors were of the opinion that the otock would soon fleld a fair dividend, which would be progressively increasing, as the commerce of the ohio had quadrupled since the canal was commenced. Tho resources of the immense western country were conetantly developing new sources of internal trade, which were annually assuming more importance. This canal afforded the only safe method of passing the falls of the ohio, and it must be used. ${ }^{1}$

The company continued to 1ssue stock to complete the cenal and to improre it for a number of years, acting in compliance with the act of the Iegielature of 1831. The first dividend was issued on June 3, 1833, which amounted to $\$ 30$ per ahare on 4,665 shares, and to $\$ 20$ per share on 1,335 shares 
the $81 z 0$ of the dividend depending upon the age of the shares, "for interest, and the tollo before that time received and expended in completing the canal. "n This Inttial dividend was paid in now stock.

The annual report of the company for the year 1833, ahowed that the oum of $\$ 10,850$, payable in the new stock of the company, remained to be Isaued; of which sum $\$ 10,100$ had beon called for, and 101 shares of stock had been delivered to stockholders, leaving a balance of $\$ 750$ due on that account.

In 1834, the company owed, in ansettled accounts, about $\$ 2,500$, and had claimg for stone sold during the year, for about $\$ 2,000$.

The piles of stone on the bank continued to fall into the canal, but were removed at intervals and used to build permanent wells on the gides of the canal. About 2,000 yards of this wall were lald during the sesson of 1834. From the frequeney of meoting of boats in the canal, by not conforming to the regulations on that subject, one or more turn-out 
places were found to be necessary, and one was begran. In August the water was shat off from the canel, and the mad and stone were removed. The entrance was widened about fifteon foet.

A special meeting of the stockholders was oalled in Norember to consider a revision of the tolls. A decision was reached to continue the toll on steam boats at forty conts per ton, actual mosurement, and to modify that of flat boats, keel boats, otc. by charging two cents per square foot of their area, instead of the specific sums pretiously oharged. 1

The first agitation for national ownership of the canal came in March, 1834, whon bill was reported to the House of Representatives from the Committeo on Roads and Canals arging the purchase of stock in this canal, and the making of the nav1gation of the Ohio River "free to all." "The munificence of the gorernment," saye the committee, "has been often extended to the stlantic States, in expenditures on the sea-board and elsewhere, and now every sentiment of justice and impulse of patriotism

$$
\text { 1. Senate Journal (Kentuch ), 1834-1835, p. 13\%. }
$$


plead for the exercise of the same liberality toward

those who inhabit the Valley of the Mississippi." l

In the eleventh annual report of the

compang to the Iegislature, the Directors stated

that

the holders of the loans created by the company arailed themselves of the right reserved to them in the contract, to convert the amount of the same into capital stook of the company. 1,560 ahares of stook were issued in this cause, amounting to $\$ 156,000$.

To pay interest on loans and to obtain money to complete the canal, the Board directed the sale of 150 shares of stock, making the total issued, 9,427 shares, and the capital of the company $\$ 947,350$.

In view of the belance on hand, the funds of the company warranted a final dividend of four per cent on the 7,717 shares of stock ontitled to same, thus making the dividend for the year eight per cont.

In comparing the number of flat and keel boats that have passed this year with that of last, the difference will be seen to be striking; to account for which it is only necessary to observe that, at the sesson when most of the craft of that description descend, the water was sufficiently high to admit them over the falls. From which circumstances the number of steam boats has increased in a still greater proportion. 2

An example of the businesslike dealinge between

1. House of Representatives Report No. 348, 46 Congress, 2nd Session, p. 4. Fob. 27, I880.

2. Senate Journal (Kentucky), 1835, pp.102-104. 
the canel company and the United States Government can be seen in the following paragraph:

\begin{abstract}
In the year 1836, the collector of tolls on the conal requested the secretary of the Treasury to delay caling for the dividend then due the united States until a petition should be acted upon, which was at the time before Congress, praying that body "that they would forego these dividends provided the canal company would bind itself to reduoe the toll in proportion." The Socretary replied that he would "be happy to refrain from using the money until Congress could act on the memorial;n but that in the moantime the amount due "must bo paid into the Iouidrille serings Bank to the credit of the United States, and a certificate of the fact furnished the department." 1
\end{abstract}

The expenditure in 1837 , towards the completion of the canal, was $\$ 5,942.05$, and fifty shares of stock were sold in January 1838 for $\$ 6,050$ to mett the seme. During 1838, the amount expended on the same account was $\$ 20,846.30$, to replace which, 200 shares of stock were sold in Philadelphia for $\$ 26,000$ which left a balance of $\$ 5,361.65$ to be appropriated towards the permanent improvement.

The unprecedented continuance of low water during the most profitable season of canal operation in 1838, lessened the recolpts by twenty-five to thirty thousand dollars, and instead of five per cont, a dividend

1. Honse of Repregentatives, MBC. DOC. HO. 83, 40th congress, 2nd 8ession, p. 18 . 
of olght per cont would, in the ordinary state of the river, have been paid.

However, the low water was a great aid in the completion of the canal. A pair of new gates were put in at the upper lift lock, and the head of the canal widened by twenty-five feet. ${ }^{1}$

By the reports of the company for the years 1839 and 1840 , it was shown that the sum of \$32,261.18, had been expended torard the completion of the canal. During 1841, the further sum of $\$ 5,832.10$, was expended for the same object, making the sum of $\$ 38,093.22$, for which new stock was authorised to be rold. But, in consideration of the "impolicy" of increasing the stock to an indefinite amount, the Board determined thet it would be for the best interests of the stookholders to limit, for the present, the number of shares to 10,000 . Thus making the capital stook of the company one million dollars, and to appropriate the necessary amount for the final completion of the oanal from the receipte of toll. They therefore, sold 217 shares of stock to make up the number to $10,000.2$

\section{Sengte Jonrnal (Kentuckv) 1838-1869, pp. 150-152.} 8. Ib1a., 1841-1842, pp. 101-108. 
The following table reveals the success of the canal from the yoar 1831 to the joar $1842:^{1}$

\begin{tabular}{|c|c|c|c|c|}
\hline Tear8 & Steamboata & $\begin{array}{l}\text { Plat and } \\
\text { Boots }\end{array}$ & Tons & $\begin{array}{l}\text { Amounts } \\
\text { Rocolived }\end{array}$ \\
\hline $\begin{array}{l}1831 \\
1832 \\
1833 \\
1834 \\
1835 \\
1836 \\
1837 \\
1838 \\
1889 \\
1840 \\
1841\end{array}$ & $\begin{array}{r}406 \\
458 \\
876 \\
938 \\
1,256 \\
1,188 \\
1,601 \\
1,058 \\
1,666 \\
1,231 \\
1,031\end{array}$ & $\begin{array}{l}421 \\
179 \\
710 \\
623 \\
355 \\
260 \\
165 \\
438 \\
578 \\
392 \\
309\end{array}$ & $\begin{array}{r}79,323 \\
70,109 \\
169,885 \\
162,000 \\
200,413 \\
182,220 \\
248,374 \\
201,750 \\
300,406 \\
224,841 \\
189,907\end{array}$ & $\begin{array}{r}12,760.77 \\
25,756.12 \\
60,736.92 \\
61,848.17 \\
80,165.24 \\
88,348.23 \\
145,424.69 \\
121.107 .16 \\
180,364.01 \\
134,904.55 \\
113,944.59\end{array}$ \\
\hline
\end{tabular}

The following teble of dividends shows the returns to the stockholders from the enterprise:

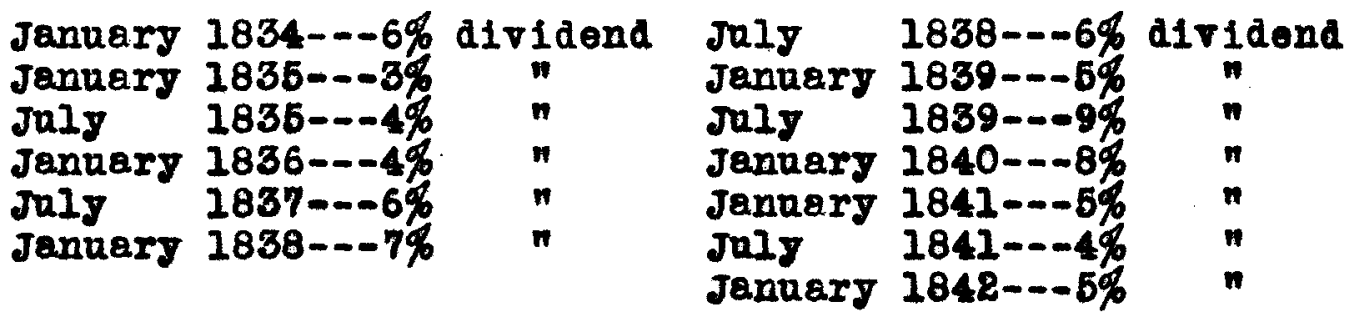

There are several items of interest in these reports. They reveal that the trafic generally was on the increase up to and including 1839, the fluctustions being accounted for by the stages of water in the river. In Senate Journels for the corresponding years. 
The recelpts of the toll depend mainly on the state of water in the Oh10, which is affected by the woather, and it will at once be seen that the amounts received mast depend on the seasons, and are as variant. At times of very high water, the boats conld pass orer the falls and avold going through the 10cks. During some winters, traffic was impeded by ice floes. The dividends on the whole were large, and the stock sold above per value. It 10 interesting, that for the supposedig bad year of 1837, the canel investors recelved dividends amounting to thirteen per cent for the business of the year.' The table of dividende gives eridence that the worst condition did not preveil in 1837, the panic year, nor in 1838-1839, but that the depression reached a climax later. Salos of pablic lands, westward migration and prices of commodities reveal the same truth, that the worst years were 1840-1842.

1. The writer has beon unablo to Ilnd ang percentage records for dividends that may have been declared in July, 1836, January, 1837, or July, 1840. Tho jear 1836 mest here been good one, and dividends must have been declared. Howerer since the total amount paid for dividends in 1840 was only onethird that of the previous jear, it 18 probable that no dividend was declared in Jaly of that year. 


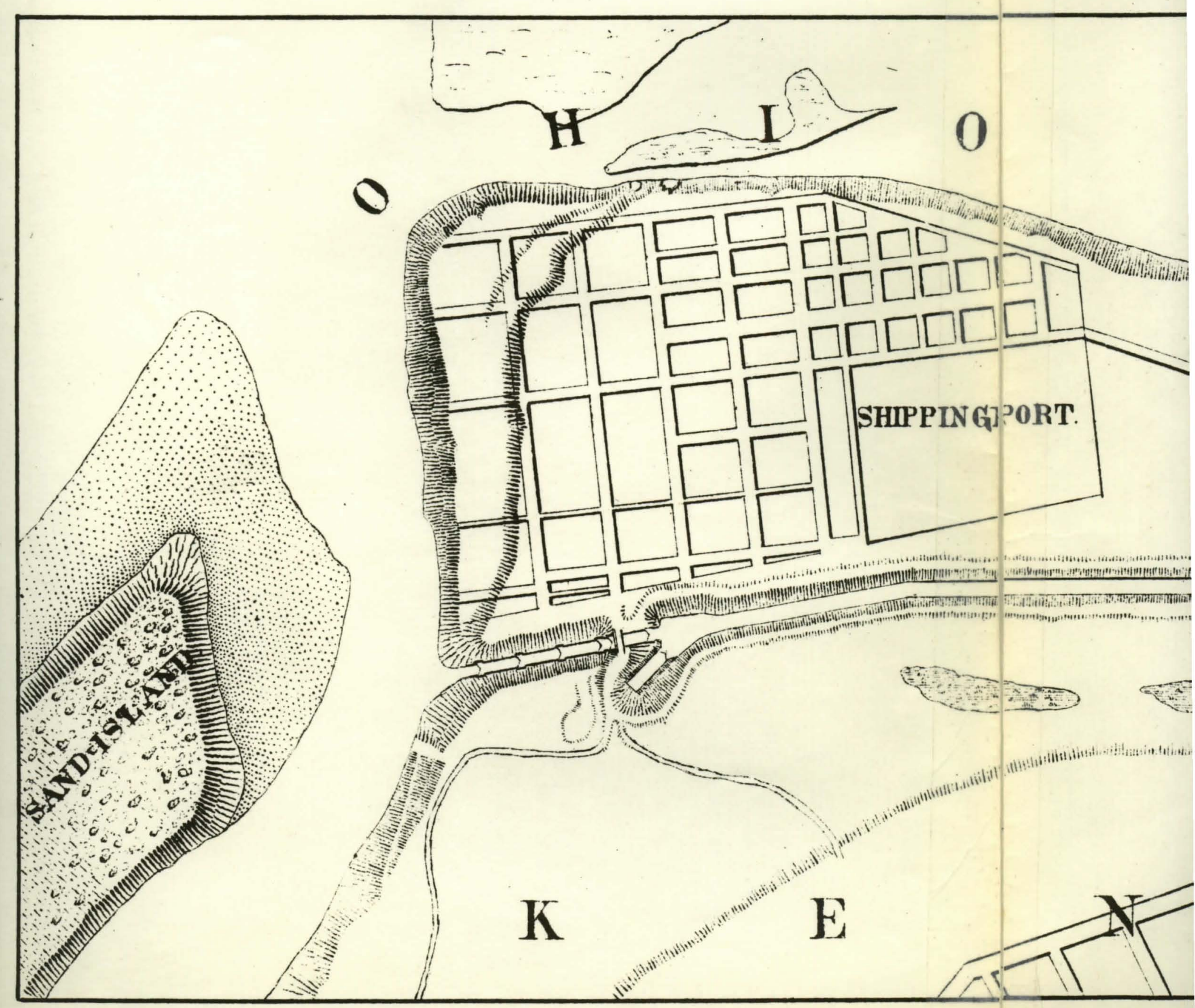

Note: From surveymadebyLt:Cot: A.H.Long TE 1018. 


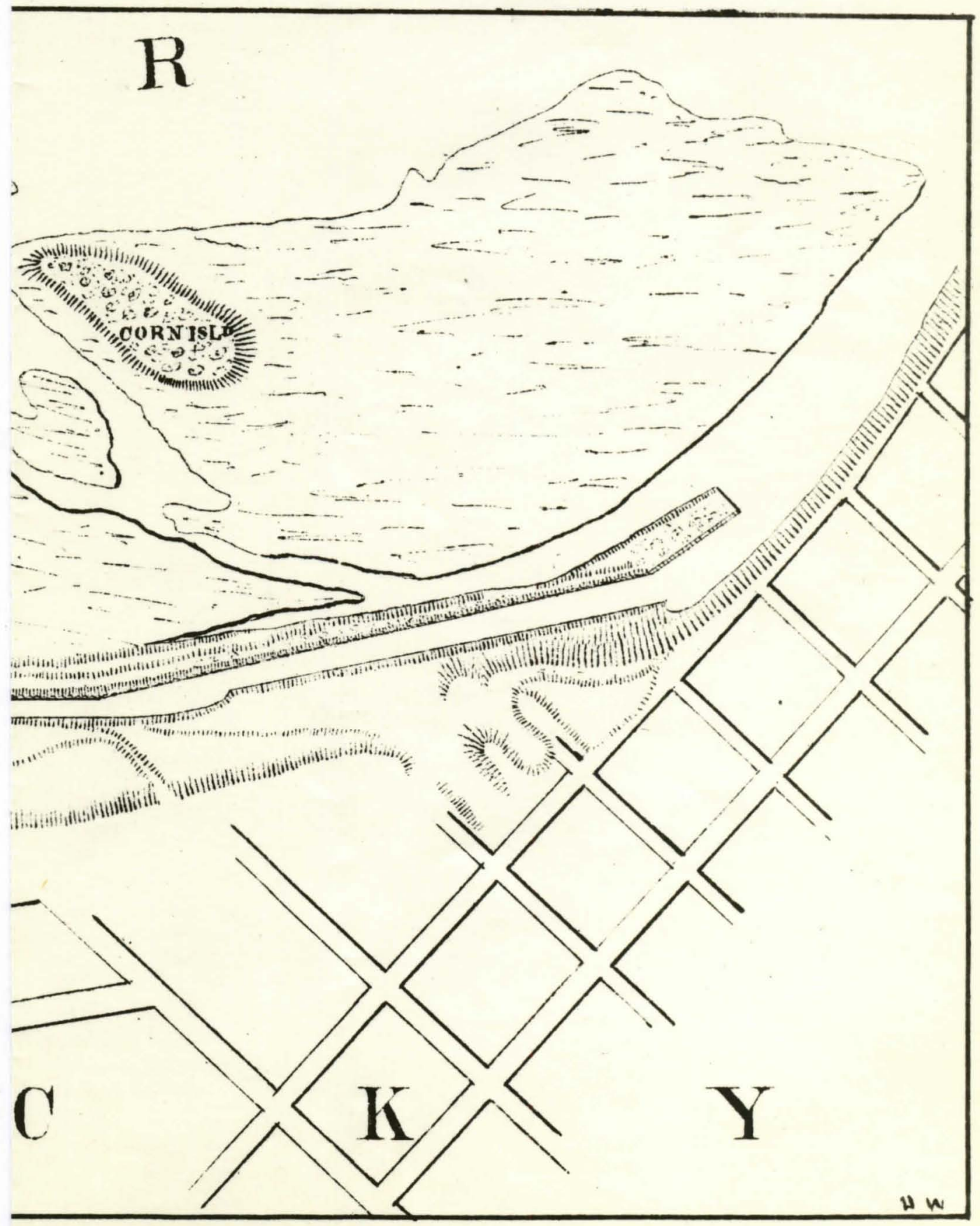




\section{CHAPTER III}

From Januery 1, 1842, to January 31, 1855, when the purchase of the individual stock (except the five shares retained by the mombers of the board) was completed. 


\section{CHAPTER III}

From January 1, 1842, to January 31. 1855, when the purchase of the individual stook (except the five shares retained by the nembers of the boerd) was completed.

Ho sooner was the canal in operation and jielding dividends, than a movement was started to bring about public ownership in order to establiah practioally froe passage for traffio.

With a view to the accomplishment of this object, an act was pasged by the leglolature of Kentuoky, which was approved January 21, 1848. This act amended the charter of the company, so that in lieu of declaring dividends, the board of directors were authorized to purchase stock held by privete Individuals with the net income, and that when these shares were all purchased, to transfer the same to the United States on the condition thet the government would only levg sufficlent tolls to keep the same in repair and pay the necessary superintendence, custody and expenses, and make all neceseary 1mprovements so as Iully to answer the purpose of its establishment. 
The law provided that, "the maximum price paid for the shares purchased the first jear, and six per contum per annum, annually, aded thereto, shall be the highest price which shall be paid for the shares in each subsequent year." ${ }^{l}$

The act of 1842 also gave the company the "privilege" of selling the shares of stock owned by Individuals to the state of Kentucky, or to the city of Iouisville, but both refused the offer. 2 ro further dividende were declared, the shares of individusls boing purchased and held in trust by the Board of Directors for the United states.

The stockholders met on July 4, 184R, and accepted the amended charter nnanimously. Mr. John Hulme, superintendent of the canal, represented the stock owned by the United States ander a power of attorney from the Secretary of the Treasury, and rerbally accepted the same, although he did not have his vote entered of record; he had recelred no instructions from the Secretary of the Treasury. although he had given the latter dive notice of the time and object of the meeting.

1. Kentucky Statutes, 1841-1842, pp. 17-19.

2. Collins, LeVIs, Op. o1t., V.I. p. 563 . 
After December 31, 1842, the compeny, in pursuance of the provisions of this amended charter, discontinued all further dividends and proceoded to appropriate the net proceeda of the canal to the purchase of the private stock.

Accordingly, notice was given each stockholder, and bids solicited for the seling of their shares, to which answers were returned from all except the owners of about twenty shares, at the maximum price of $\$ 150$ per share.

It was estimated that the balance on hand December 31, 1842, would enable the Board to purchase about 400 shares of the stock of the company under the provisions of the Act of 1842 .

The canal was reported to be in first clasa condition, and it was believed that by a etrict attention to the removal of obstructions, as soon as oreated, but little expense would be required for many Jearв.

The recelpt of tolls for the year 1842 was greatly diminished due to the difficulties and embarrassments in the commercial affairs of the country, and the long continued high water in the ohio. However, an increase of tolls for the next 
and succeoding jears was confidently anticlpated. ${ }^{2}$

In the 19th Annual Report of the President and Directors of the Company to the legislature of Kentuoky, it was stated that 471 shares of stock had been taken in and peid for during the year 1848, and that in viow of the balance of cash on hand Decomber 30th, 1t was estimated that upwards of 500 shares could be purchesed during the next year. This number, added to the shares elready purchased would make the United states, virtually, the owners of about twofifthe of all the shares in the company, and by the operation of the law, they would have a major part of the stock in two jears.

The canal was reported to be in good condition; new gates and a drawbridge with other necessary repairs, hexing increased the expenses of the past year. From the complaints made by the commercial commanity concerning the high tolls, the board was induced to reduce the rate from sixty to fifty cents per ton. 2

On the 10th of Februery, 1844, the House of Representatives of the United States, by

1. Kentucky Doouments, 1842-1843, p. 294 .

2. Senate Journal (Kentroky), 1843-1844, pp. 62-63. 
resolution, oalled upon the seoretary of the Treasury for cortain information relative to the Iouidille and Portland Canal---the condition of the rork, the mount of tolls collected, the effect of such tolls upon the commerce of the river, whether the canal was of sufficient capacity to accomodate thet commerce, and as to the desirability of onlargomont. The secretary (Mr. Spencer) immodiately communicated these resolution to the survejors of oustoms at Cincinnati, Louisville, and St. Louin, and the president of the canal company, at Louisville, oalling for the information desired; and on Fobruary 22nd he communicated to the speaker of the House the Beveral replies of these officers, which were, on the 26th, read and referred to the committee on comerce. The surveyor of Cincinnati, in his reply. atates that the expense for tolls to a regular trader botwoen that oity and st. Iouls, of one hundred and ninety tons burden, costing originally, when complete and ready for service, $\$ 13,000$, was $\$ 4,000$ per year, or \$20,000 for the period of her natural 11fe, "Bay five years." He further estimates the cost for tolls of "one of the largest class of steam vessels" plying 
regularly between Cincinnati and New Orleans at $\$ 2,400$ per year, or $\$ 12,000$ for five jeara. The surveyor at Loulsville gives four years as the average life of a Louisville and New Orleans trader, and in reference to the inquiry "concerning the improvement or finishing of the canal," he saye that "1f it is to remain at its present size, it is complete and in good order; but it is my opinion it should be enlarged as soon as practicable, as its capacity to pass steam boats of the present day 18 entirely too small."

The president of the Louisville and Portland canal, in his reply, ostimates that a cincinnati and New Orleans trader, "of say three hundred tons," will pass the canal ten times in the course of a joar, and in five years pay for tolls $\$ 7,500$, or nearly onethird of her original cost when completed, equipped, furnishod, and proviaioned for a voyage. A Pitteburs and st. Iouis trader of two hundred tons, passing the canal only ten times, which would be but five trips and return, would in the five jears of her life pay no lese than $\$ 5,000$, or within a fraction of one-third of her cost when first ready for a voyage. 
The fourth section of the amended charter of the oansl company, passed in 1842, having been deemed objectionable, an application wer made to the Gonoral Assembly in 1844, and the following act was passed:

Be it enected by the General Assembly of the Commonwealth of Kentucky, that in the erent of the United states becoming the sole owner of the Iouisville and Portland canal, the jurisdiction of this Commonwealth shall be yielded up to the Government of the United States; and no annual report, as mentioned in the charter of the company, hall be required to be made by the United States, or their Agents or superintendent's of sald canal, to the General Assembly of this Commonwealth. 1

Thus Kentucky had done its part in aiding the United States to take orer the canal by removing -verg objection on the score of jurisdiction. On the 20th March, 1844, the secretary of War ( $\mathrm{Nr}$. Wilkins), in response to a resolution of the Senate of the 218t Fobruary of the preceding year, communicated to the President of the Senate a report upon the subject of the Louisville and Portland canal from the chlef of the corps of topographical engineers. This report, besides considering the various profecte then suggested for improving the navigation of the 
Ohio river at the falls, presented the benefits and defects of the canal as it then existed, the cost of the work to that time, the number of shares of stock owned severelly by the United States and by individuals, the total sum of the tolls received, and the aggregate amount of the tonnage passed from the period of the first opening of the canal. In discussing the benefits of the canal in his report, Captain T. J. Cram of the U. S. Corps of Topographical Engineers ang that

although the canal has taken toll, the commerce of the Fest has annually realized a benefit of $\$ 180,788$ as a direct consequence of the construction of this work, to say nothing of the saving of the item for pilotage over the falls; and should the present policy obtein, of allowing the canal to continue its tolls, still, this commerce would also continue to be annually benefitted by the canal by the sum of $\$ 180,788$. But, should the canal become free, an additional advantage would accrue to commerce, and the measure of this is now to be estimated thus: The annual sum, on an averate, collected as tolls, has been $\$ 93,362$. This, would of course, have been an aditional annual saving to commerce, had the canal been maintained without charge to the crade. Therefore, the same rate of business continuing, there will be the sum of $\$ 93,362$ as the measure of the additional saving that would be consequent upon rendering the canal frea.

Iet it be supposed, now, that tolls be charged only to realize annually the sum 
of \$25,000 for maintalning an improved canal. This sum taken from $\$ 93,362$, w111 leave $\$ 68,362$ as the measure of thet additional saving; and if we take into account an increase of business of only twenty-three and one-half per cent, wo shall find the measure of the additional saving to be $\$ 84,427$ annually.

This saving in the next fifteen years will amount to $\$ 1,266,405$, which is near the cost of al1 the required improvements, the stock yet to be purchased from individuals, and of the dry dock. If the business should increase by fifty per cent, the annual additional saving would amount to that sum in twelve and one-third years, commenoing from the first of January. 1844.1

According to the twentieth annual report of the canal company. 544 shares were taken in during 1844, and from the balance of cash on hand, an estimated 770 additional shares of stook could be purchased during the ensuing jear. During 1844, the canal was actively employed, and a greater amount of tonnage passed than in any former jear. Howerer, reduction in the rate of toll, made the net rooeipts less than in 1839, while there was an increase on those of 1843 by upwards of $\$ 33,000.2$ on the 86th of December, 1844, the House of Representatives of the united states passed a

\footnotetext{
1. Report of the Secretary of War, 28th Congress, Ist Session, March 20,184, p. 23.

2. Kentucky Documente, 1844-1845, pp. 477-479. (The canal and its appendencies were in good condition; it was closed for one weok during the extome low water and all obstructions removed.)
} 
resolution calling upon the secretary of the Treasury for his opinion as to the propriety of the purchase by the United States of the residue of the stook held by individnal stockholders in the Iouisville and Portland Canal Company, with view to making the navigation of the canal free from toll; and also the terms, in his opinion, on which the purohase could be made, and the probable amount of money which would be required to effect 1 t.

The Secretary ( $\mathrm{MCr}$. Bibb) replied on the 2lot of January, 1845, naming $\$ 630,000$ as the probable amount of money that would be required to purchase the stock hold by individuels, and earnestig recommonded the purchase for the purpose named. "In doing so," he remarked, he did "not confine his views to the sum of $\$ 630,000, "$ but added to "a further expenditure as essential to the great object of overcoming the natural impediment by an easy and convenient water communication, freo of the burdens and tolls upon commerce and nevigation, which are felt a grevious and much complained of by the people of the United states.n

In reply to a letter from the secretary of 
the Treasury asking for information, the prosident of the canal replied January 8, 1845, stating that the whole number of shares in the canal was 10,000, of which the United States orned by subscription, by purchase, and through stock dividends, 2,902 shares, 1,786 shares had been purchased under the charter as amonded in 1842, and that the not income of 1846 was estimated at an aggregate which would be sufficient to parchase 812 additional shares, which would leave at the close of that year 4,500 shares standing in the namos of individuals. And the president of the canal expressed the opinion that, with the declared purpose of making the work free, these 4,500 shares could be purchased for the oum of $\$ 600,000$. In the same letter he stated the average amount of tolls collected at $\$ 160,000$ per annum. This letter the secretary communioated to Congrese, approving of the purohase, recommending the appropriation, and urging speedy congressionel action. However, nothing further was done at this timo. 1

$$
\text { On the 3lst of December, 1845, in the House }
$$
of Representatives, Mr. Tibbatts, from the committee on Commerce, to whom had been referred "a petition of the 2nd session, p. 18 . 
merchants and steamboat owners of the valiey of the Oh10 and Mississippl praying Congress to purchase the individual stock in the Iouistille and Portland canel for the purpose of making it free from toll," the committeo having had the subjeot under consideration, reported in favor of the messure, accompanied by a resolution making provision for carrying into effect the object of the petition. The resolution was well sustained by argument. After being read, the report of the committee was referred to the Comittee of the Whole. ${ }^{2}$

According to the twenty-first annual report of the canel company. 771 ahares were purchased from the stockholders during the year 1846, and from the balance on hand December 31, 1845, it was estimeted that about 665 additional shares of stock could be bought during the next year. Th1s would give the Onited States ownership of 5,353 shares, leaving but 4,647 to be 1iquidated.

a slight diminution of tolls from the previous year was caused by the severity of the weather during the month of December, due to which narigation was obstructed by 100.2

1. Misc, Document I0. 83, H. OI R., 40th Congre88, 2nd session, p. 8.

2. Senate Journal (Kentucky), 1846-46, pp. 90-91. 
During the jear 1846, 655 thares were taken by the company, falling just ten short of the estimate of the previous year, and in view of the balance of cash in the troasury, it was believod that 665 additional shares could be purohesed during the ensuing yoar.

The unprecodented high water in the ohio river during the spring and fall of the jear, deprived the company of the receipt of tolls for six wooks, of the most busy seasons, which would heve given an amount equal to the most farorable year.

From the large interest of the Government of the Unfted States in the canal, the Board deemod it right to permit boats exclusively employed by the United States to pasa through the canal free of toll, many of which, with troops and munitions of wer, arailed themselves of this privilege. I

The number of shares purchased from the stockholders in 1847 plus those purchesed in 1848 , left only 2, 824 shares remaining in the hands of private individuals. ${ }^{2}$

The unusual high water in the spring and summer of 1847 caused a loss of three months toll,

1. Senate Journal (KentuckF), 1846-47, pp. 86-86. 2. Ib1d.. 184/-48, $\mathrm{pp} \cdot 69-10$. 
and the "disastrous" flood of December in the same jear ran the total amount of repairs over the two year period up to $\$ 18,000 .^{1}$

The next action taken by the National

Government in regard to the canal was in the senate, Fobruary 15, 1851, when the following resolution was passed:

Resolved, That the Secretary of the Treasury be requested to ascertain and report to the Senate what amount of the stock of the Ioulsville and Portland Canal Company was subscribed for by the United States; what was the original stock of ald company; what additional stock has been created, and how the same has been disposed of; what dividends have been received by the United states and when; what arrangement hes been made, if any, for the purchase of the stock of said company, and with what object; and whether the assent of the United States has been given to said arrangement, and if so, when and by whom; and what amount of stock is now held by the United States, and by the several individual stockholders respectively.?

In the senate, February 27, 1851, Mr. Bright, from the Committee on Rosds and Canels, to whom had been referred a bill "to remit the toils on the united states atock in the Loulsville and Portland canal Company, and to purchase the stock of individual stockholders, and to make the navigation of said canal free," submitted a report, which was ordered to be printed with a subst1-

1. Senate Journal |Kentugky, 1848-49, pp. 63-64. 2. Misc. Document, op. cit.. p. 8 . 
tute for the bill. The report declared that the committeo had been deoply impressed with the magnitude and importance of the subject, and had bestowed upon it their deliberate consideration. It then sa1d: "There can be no question that the subject is essentially national in its character, and it is a subject of regret that this canal has been so long continued an instrument of oppressive exaction on the trade and commerce of the Weat, and that the United states by being an extensive stockholder, has been a party to this oppression; and the committeo believe thet the universal public sentiment colls loudly for an immediate abatement of this stupendous monopoly, and for on adequate provision by the general government to insure the free navigation of the Ohio river, in which so many States of this Union are so deeply interested."

Again in 1852 an elaborate report was submitted to the House of Representatives in which the great "national importance" of the canal was stressed along with its "inadequacy to the purposes of its construction." The committeo reached the conclusion that, "to answer the wants of the rast and increasing commerce of that river, two canals are indispensable, 
one on each side." Consequently, a board of ongineers was authorized by the Secretary of war to report in detail on the situation. Neter having made such examinetions as were necessery, the board reported on three plans for the improvement of navigation at the falls of the ohio. The first dealt with an improvement on the Indiana side; the second dealt with an improvement on the Kentuoky side having no connection with the existing canal, and the third dealt with improrement of the Louisille and portland canel. The comitteo, after much detalled reasoning, chose the third plan. In December, 1853, the Secretary of the Ireasury ( $\mathrm{Wr}$. Guthrie) called the attention of Congress to the oanal, stating that it had becomo almost entirely the property of the United states, and requested appropriate legielation by Congress with reference to the work.

In the House of Representatives, June 10, 1854. Mr. Preston, from the Committee on Roads and canals, reported bill "to provide for taking chargo of the Louidrille and Portland canal, and to prevent the same from falling into bad repair," whioh was read twice, recomended to the comitter, and ordered 
to be printed. This bill provided that as soon as the secretary of the Treasury should be notified by the President of the canal company that all the stock had been purchased for the United states, then the Secretary should appoint the proper officers to take posseselon and control of the canal and all its works. On January 31, 1856, the president of the canal company made a special report to the secretary of the Treasury (Mr. Guthrie), stating the balance of cash then on hand at $\$ 5,148.63$, after finally liquidating the last of the individuel stock, except five shares held by the president and four directors for eligibility. The stock stood as followe:

Held by directors individually, 5 shares. Held by direotors in trust for the United Stater, 7,093 sharea.

Held by the United States, 2,902 shares.

41 general and incidental expenses had been pald to date; also the "claim of Thomas Hulme," for $\$ 5,000$, and $\$ 50,000$ for the Portlend dry-dock, according to contract previously reported. Among the expenses noted as "incidentel" is mentioned an item of $\$ 7,500$ extra compensation roted by the stockholders at their 
annual moeting in January, 1854, to be paid to the officers. The reduction of tolls 18 stated in this special report as follows: on steamboats,

- from fifty to twenty-five cents per ton; on produce flat-boats, from three cents to one and half cente per ouperfioiel foot; on hay, coal, and I1me boats, from two cents to one cent per superficial foot. The president of the compang concludes his report with the following important statements:

\begin{abstract}
These reduced rates will yield a sufficient revenue to meet the ordinary expenses of the canal, and to make some repairs that are necessary. The oanal is now ready to be transferred to the custody of the general government, 80 soon as the department may be prepared to receive it. The board of president and directors beg leave to say that they wi1l cheerfuliy continue to direct the affeirs of the work, as heretofore, so long $8 \mathrm{~s}$ the department may wish the same intrusted to their care. A plan for improving the canal has been submitted by John Hulme, of Philadelphie. The board has carefuliy examined it, and consider it so excollent and feasible that they beg leave to commend it to the favorable consideration of the department. 1
\end{abstract}

The following table shows how and when the Onited states acquired all but five shares of stook in the Loulsville and Portland Canal Company.2

1. Ilisc, Dooument, op. c1t., p. 20 .

8. Ibid., p. 26. 


\begin{tabular}{|c|c|c|c|}
\hline Year & $\begin{array}{l}\text { No. of shares } \\
\text { purchased }\end{array}$ & $\begin{array}{l}\text { Prico paid } \\
\text { per share }\end{array}$ & $\begin{array}{c}\text { rotal amount } \\
\text { paid }\end{array}$ \\
\hline $\begin{array}{l}1825 \\
1829 \\
1831 \\
1843 \\
1844 \\
1845 \\
1846 \\
1847 \\
1848 \\
1849 \\
1850 \\
1851 \\
1858 \\
1853 \\
1854 \\
10 t 81\end{array}$ & $\begin{array}{r}1,000 \\
1,335 \\
567 \\
471 \\
544 \\
771 \\
665 \\
667 \\
626 \\
634 \\
470 \\
400 \\
610 \\
530 \\
805 \\
9.995\end{array}$ & $\begin{array}{c}\$ 100.00 \\
\$ 100.00 \\
\text { stock dividend } \\
\$ 148.93 \\
\$ 159.00 \\
168.00 \\
177.00 \\
\$ 186.00 \\
195.00 \\
204.00 \\
\$ 213.00 \\
\$ 22.00 \\
\$ 231.00 \\
240.00 \\
251.17 \\
. .\end{array}$ & $\begin{array}{r}\$ 100,000 \\
133,500 \\
\text { for } 80 \text { rued interest } \\
70,145 \\
86,496 \\
129,528 \\
117,705 \\
124,062 \\
108,570 \\
129,336 \\
100,110 \\
88,800 \\
140,910 \\
127,200 \\
202,200 \\
\$ 1,652,562\end{array}$ \\
\hline
\end{tabular}

sdaing $\$ 56,700$ to the total amount paid column, which Is the amount of the dividend for which otock was accepted by the United States in 1831, we see that the number of shares purchased was 9,995, and the cost was $\$ 1,709,262.00$.

The complete statement shows that the United states became the sole owner of the Iouisville and Portland Canal in the year 1855, with the exception of five shares of the canal atock held, one each, by five gentlemen, for eligibility as directors. It shows further, that the United States acquired this property without actually paying one dollar from the national treasury. And still further, it shows that, in adition to the property thus obtained, it acquired 
58.

$\$ 24,278$ in monej, that sum having boen paid to tho United states in the form of cash dividends bejond the sum originally invested by the government in the stock of the company. 
CHAP TER IV

From January, 1855, when the United States acquired control of all but five shares of stock in the canal. to 1868, when Congress ordered a new survey and report to be made on the navigation at the falls of the ohio. 


\section{CHAPTER IV}

From January, 1855, when the United States acquired control of all but fire shares of stock in the canal, to 1868 , when Congress ordered a new surveg and report to be made on the navigation at the falls of the ohio.

On February 8, 1855, the Secretary of the Treasury wrote to the President of the United Stetes that, "as heretofore explained," the board of pres1dent and directors of the Iouisville and portland canal had by him been requested to retain one share of the stook of that company, in order that no difficulty might arise in the management of the work. He at the same time enclosed a report to the president which he had received from the president of the canal, showing that all the stock but the five shares thus retained had been redeemed, that the work was free of debt, and that the tolls had been reduced one-half, (to twenty-fire cents per ton.) In closing his letter to the President of the United states, the Secretary of the Treasury said:

The canel, with the exception of the fire shares, is now the property of the United states, and may, as Congress shall direct, be enlarged to suit the trade of the ohio, 
as suggested by Mr. Hulmo, (in an accompanying letter, from the tolls, or by surrendering the canal to the commonwealth of Kentucky, on such terms as 111 secure the same object and make it freo.

On this letter the President made the following indorsemont:

Return the papers to the Treasury Department. V111 the secretary bring the subject to special notice before the meeting of Congress?

On the 14th of March, and again on the 7 th of April, the secretary of the Treasury wrote to the president of the canal requesting, further, his views with reference to "Hulme's plan" of improving the work.

The president of the canal replied to both letters in one, April 12th, presenting his matured views somewhat in detail. In this letter. referring to the narrowness of the canel and the ledges of rock that jutted from its sides, he said, with referenoe to steamborts:

The difficulty of getting through without serious damage to their wheels and machinery makes it necessary for them to move so slowiy and cantiously in low water that it is not an uncommon thing for a boat to spend twelve houre in passing through the canal. Were the projecting ledges removed, very few of the boats would require more than one or two hours. 


\section{Again:}

If the canal had two additional basins, boats might readily pass each other, and a number of them might be in the canal at the same time. This would enable us to do much more business, and would prevent the rexatious delays that are at present unavoldable. A guard gate and a floating boom were much needed.

$$
\text { On April 20, 1855, the secretary of the }
$$

Treasury wrote to the president of the canal as follows:

Your favor of the twelfth instant hes been received and considered. I concur with you that if $\mathrm{N}$. Hulmo's plan of repeiring the Ioulsville and Portland canal should be adopted, that only a part of it should now be carried out; and that part jou indicato, beoause that part would not commit the company to the enlargement of the locks, but leave that question open to a mature consideration; and whatever may be the ultimate mode of enlargement that may be adopted, the other parts of Ir. Hulmo's plan will be proper to a convenient navigation of the canal. Ind you will, therefore, be authorized to contract: 18t. For the guard-gate; 8nd. The removal of the ledges on the margin of the canal: 3rd. The basins; 4 th. The floating boom at the head of the canal. In making these contracta you will have the work done as speedily as possible; but as peyment can only be made out of the surplus tollo, that fact must be declared in your contracts. so that no liability shall accrue against the company, the payment of which is not to await the recelpts of the canal. This is written upon the predication that the contract is preferable to doing it by days. work and a euperintendent, but thet may not be the case. 
Upon the original of this letter is the following indorsement by the President of the United States:

Iet the improvements be made with the tolls, with the distinct understanding that tho government commits itself to nothing involving a material change in the capacity of the canal and locks; incidental expenses to be strictly within income at reduced tolis, as proposed.

In May, 1855, the president of the canal advised the secretary of the Treasury that day labor, directed by competent superintendence, would be cheaper and more efficient than a contract for the work planned.

In June, 1856, Colonel s. H. Long was appointed by the secretary of war to prepare a plan and estimate for a new set of locks for the Louisvillo and portlend canal. The president of the oanal reported to the secretary of the Treasury that the board of directors had also employed an engineer for the same purpose. The latter's report was forwarded to the Seoretary, but was considered by the president of the canal, who sent it, to be at least twenty per cont too 10w.

1. House Document Ho. 83, 40th Congress, 2nd Session. pp. $20-21$. 
In August, 1856, the Secretary of the Treasury in a letter to the president of the canal, said that the plan and estimates for the new locks had been directed under the expectetion thet congress might make an appropriation in order to make the canal sufficient to pass the larger vessels; but that expectation hed not been realized. The president was authorized however, to secure the necessary land for the construction of new locks.

In September of the same jear, Colonel Iong's plans and estimates were sent to the president of the canal for his consideration. He immediately wrote his opinion to the effect that the plans wero liable to many serious objections, and expressed doubt as to whether they could ever be put into use. He said that h1s opinion was sustained by the unanimous voice of the steamboat men, and of all the engineers (except Colonel Long) that had ever examined the location. The canal president further stated that the work then under construction would probably be completed within thirty days.

In August, 1856, a b1ll for enlarging the Iouisville and Portland oanel, or improving by other means the navigation at the falls of the ohio, was 
reported on in the United States House of Representatives. The bill provided for appropriating the sum of $\$ 600,000$ to the purpose of enlarging the canal," and for "a reduction of tolle to an amount" (ten cents per ton) "only nocessary to keep it in repair and pay cost of management." Howerer, the matter got no further at this session.

In the Senete, January 14, 1857, the following resolution was passed:

Resolved, That the Secretary of the Treasury be requested to inform the Senate the number of shares of capital stock of the Louisville and Portland canel company now belonging to the United States, and also of those owned by other persons or corporations; how and by whom the tolls levied on the passage of ressels and property through the Ioularille and Portland canal are collected; the rates of toll, the gross annual amount thereof since the first of January, 1850; the expenses of colleotion, ouperintendence and repairs, and the net revenue subject to division among the stockholders; also, by whom the rates of toll are now reguleted; and generally all information which in his opinion may be promotive of proper legislation on the subject of said canal.

Accordingly, the Secretary of the Treasury wrote the president of the canal asking for the required information. The president reported these facts, and in adition listed the annual amount of tollo collected

1. House Document, op. c1t., p. 13. 
from the first of January, 1850, to Januery, 1855 , with the expenses of collection, superintendence and repairs.

On the 25th of November, 1857, in response to a communication of the 4 th from the Secretary of the Treasury, ( $\mathrm{Mr}$. Cobb,) calling for a report, nembracing such facts and information as may be usefal and interesting to the public," the president of the canal wrote at considerable length. He sets forth the fact that, acting under the charter of the company, 88 amended by the legislature of Kentucky, in February, 1842, the board had from year to year appropriated the net income of the canal to the purchase of the individual stook, until, on January 318t, 1856, the amount then on hand being sufficient to extinguish all that remained, he "announced to the department the readinese of the board to tender the custody of the canal to the United states, upon the conditions prescribed by the amended charter. The department, he says, "replied that there had been no legiblation authorizing the acceptance of the canal, and requested thet the president and directors should each retain one share of stock," for eligilility as a managing board, and continue the management until there should be legis- 
lation upon the subject by Congress, which they consented to do; and their management of the canal, he says, was "with strict reference to the requirements of its charter." The improvements as suggested by $\mathrm{Nr}$. Hulme, and authorized by the concurrent ection of the Seoretary of the Treasury (Mr. Guthrie), and the board of president and directors, were nearly completed, and at the date of his letter he believed there was money enough on hand to finish them nand purchase the ground yet required for the branch canal." That balance he stated at $\$ 53,523.95$. The improvements effected were important; they materialiy increesed the facilities and safety of navigation, and gave great satisfaction.

By an act of the legiglature of Kentucky, approved December 19, 1857, it was declared

that the charter of the Iouisvilie and Portland canal company be so amended as to authorize said company to construct with the revenues, and on the credit of the corporation, a branch canal sufficient to pass the largest class of steam ressels navigating the Ohio river; and eaid company are hereby vested with all power and authority to acquire and hold the nocessary lands for such branch, and to construct the same, vested by the charter and amendments for the construction of the original canal, and all the provisions of the original charter and amenaments shall be, and are heroby made, as 
applicable to the branch as to the original canal. 1

On the 26th of May, 1858, the Secretary of the Treasury (Mr. CObb) wrote as follows to the president of the canal oompany:

Referring to the report made by jou on the 25 th of Norember last........ I have to sey that you will take no further steps........ and make no expenditures of the company's revenues........ beyond keeping the canal in repair.......unt1l you are further advised by this dopartment, as all the facts in the case will be reported to Congress for its action.

The recoipt of the Secretarg's letter "by due course of mail," was acknowledged by the president of the canal company. This gentleman at that time informed the secretary that before the receipt of the latter's correspondence, contracts had already been entered into for the purchase of all the real estate which would be required for the future use of the canal.

The president of the canal then took issue with the secretary of the Treasury orer the latter's assumption that he possessed the controlling roice in 1. Kentucky Statutes, 1857, p. 223. 
the affairs of the company. The president pointed out that the directors were but trustees of the stook acquired under the operation of the act of 1842, but that the United States were not the proprietors of any otock in the company beyond the shares held absolutely on the 218t day of February, 1842, and in the management of the affairs of the company were ontitled legally to no further control than by the rote of seid stock they could give to the company in the selection of its officers. The president further stated that it was his opinion that a reasonable period had already elapsed within which Congress might elect to take over the control of the canal, but that he had been instructed by the board to say that until congress should again have had an opportunity to legislate upon the facts, and to elect whether the United states would undertake the trust declared by the statute of Kentucky, the president and directors would continue to conduct the affairs of the company nas to observe with all fidelity the preservation of such surplus as shall represent the shares of the United states compared to the aggregate belonging to the whole stock of the company." 
In his annual report to the Legislature of December 22, 1859, on the state of the finances, Mr. Cobb again presented the subject of the canal, saying its condition was "so anomalous as to require the aotion of Congress." After repeating facts often stated before, the Secretary concludes his reference thus:

$$
\begin{aligned}
& \text { Under the laws of Kentucky the United states } \\
& \text { are substantially the owners of the canal, } \\
& \text { but no authority has been given to supersede } \\
& \text { the corporators in its mangement, no action } \\
& \text { having been had on this subject since the } \\
& \text { amended charter by Kentucky. Under these oir- } \\
& \text { cumstances, I would refer the whole subject } \\
& \text { to Congfess for such action as they may deem } \\
& \text { proper. }
\end{aligned}
$$

In 1860, the legislature of Kentucky passed a series of resolutions, which were approved by the governor of the state on the lat of March, declaring that the commeroial interests of the Mississippl valley imperatively demanded an enlargement and Improvement of the Louisvilie and Portland Canal, and that the money already inrested in said canal by the United States government would prove of little public benefit unless the work should be enlarged and extended. And the senators and representetives from

1. House Document, op. cit.. p. 15. 
Kentucky, and the Congress of the United states, were earnestly requested by these resolutions to procure an appropriation by Congress adequate to the exigency of the case, and to adopt such measures a would Insure a speedy enlargement and completion of said conal. ${ }^{1}$

Finally, through the persevering exertions of the immediate representative of the Louisville district ( $\mathrm{Mr}$. Mallory), Congress passed the following jolnt resolution, which was approved by the President May 24, 1860:

Resolved by the Senate and House of Representatives of the United States in Congress assembled, Thet the President and directors of the Louisville and Portland Canal company be, and they are hereby, authorized, with the revenues and oredits of the company to enlarge the said canal, and to construct a branch canal from a sultable point on the south side of the present stream, to a point on the ohio river, opposite sand island, sufficient to pass the largest class of steam ressels navigating the ohio river: Provided, That nothing herein contained shall authorize said president and directors, directly or indirectly, to use or pledge the faith or credit of the United States for the said enlargement or construction, it being hereby expressly declared that the government of the United states shall not be in any monner liable for said enlargement or construction: Provided further, That when said canal is enlazged, and its branch canal is constructed, and its cost of said improvement paid

1. Senete Journel (Kentuoky), 1860-61, pp. 201-203. 
for, no more tolls shall be collected than an amount sufficient to keop the canal in repair.

Immediately after the act of Congress of yay 24, 1860 had been approved, the directors of the canal raised money by issuing bonds, purchased land, and engaged the services of Mr. Theodore R. Scowden, a distinguishod hydraulic engineer. Under his direction detalled plans were prepared, and the work of enlargement wos commenced. The Civil War so increased the cost of labor and material that the estimates were greatly overrun, and in 1866, after expending about $\$ 1,825,403$, the directors were compelled to suspend the work. 2

The engineers estimate of the cost of conatructing the branch canal was $\$ 853,770$, and the bid accepted for the work was $\$ 865,186$. Actually, the sum expended was $1,060,023.20$, leaving it still unfinishod. This shows an excess of the expenditure for work done, over the contract price for the whole work as $\$ 194,838.20$; of which excese the following explanation is drawn from the records of the company. At the regular meeting of the board of directors for the month of September 1863, a 
communication (dated the twentieth of the preceding month) was presented from the contractors, setting forth that inesmuch as the contracts under which theg were working were made at a time when the United States, in both its home and its foreign relations, was in a condition of ordinary quiet and repose, from which no human sagacity or foresight could have anticipated the acts and relations that within a short time succeoded; and that inasmuch as that labor and materials of all kinds had, in consequence of the changed condition of affairs, increased in the average more than fifty per cent, (which statements were accompanied by the relation of many facts fully verifying them) they, the contractors, felt justified in every respect in requesting the board, after a thorough investigation and consideration of the whole subject, to incresse the prices at which they had contracted to execute the several descriptions of the work at least thirty per cent from the first of January preceding. "that boing about the time when prices reached their maximum, " as otherwise ineritable ruin was before them; and that which would break them down would of course render 1mpossible the fulfillment of their obligations, and retard materially, if not postpone for an indefinite time, the important work which they had undertaken to 
construct. The contractors presented an alternative for the coneideration of the board. Which was, that if the latter should so prefer, they would throw up and cancel their contracts, and make a just and satisfactory arrangement with reference to the machinery prepared expressly for this work, which they were using. An egreement wos made by the board, whereby the adrence should be made from the first of september instead of the first of January, and the work was prosecuted with renewed energy. However, in April, 1864, a similar communication was received from the contractora, and a similar settlement was made, the adrance on the contract price being made from May, 1864. In March, 1865, prices of labor and materials having still further adranced, a third communioation was adressed to the board. It was deemed inexpedient howerer, to make any further adrance in prices, so the board thought it best to accept the surrender of the contracts, and proceod with the work by day labor and small contracta as fudiciously as possible, directing their means and energies as much as they could to such pazts of the general work as would, when they should be compelled to stop for the want of money, leave the enlarged oanel in the best condition for the increased demends that would 
henceforth be made upon it.

Nr. W. D. Gallagher, special agent of the

Treasury Department, was anthorized to make a report

on the Louispille and Portland canel in September.

1867. At the conclusion of his report, and in regard

to the debt owed by the canal company for 1ts un-

finlahed Improvements, he says:

Contrary to my understanding when this investigation was commenced, this debt was legitimately contracted under both state and national authority. and contrary to what I believe is the general

impression, the improvements made in the canal from time to time, and the use of the moneys and credits of the company to offect the same, were with the concurrence of the secretary of the Treasury for the time being, expressed or implied, and the knowledge of at least the appropriate standing committees of Congress, derived from information communicated from the Treasury Department; wh1lo the purchase of land for the branch canal, and the enlargement and improvement of the old canal. were directly authorized by the secretary of the Treasury (so far as he hed the power to authorize them) in the Month of March, 1857, by the legielature of Kentucky in the same year, and by the United States Congress in May, 1860.

In regard to the management of the canal in

1867. Mr. Gallagher goes on to say:

An anomaly appears in a condition of things in which five private gentlemen, constituted trustees for the United States by the legislature of a state, without spocial responsibility anywhere, and holding and exercising the power to name and constitute their successors, whom neither the secretary of the Treasury nor the Congress of the United States, nor any other national authority, can removo or control by 
ordinary means, or by any means other than those prescribed by the legielature of the State aforesaid, hold and control public property that has cost millions of dollars. collect a heavy tax upon the commerce of on most important rivers. Which they can increase at their pleasure, and expend in their discretion, for salaries, operating machinery. improvements, and extensions, the moneys thus obtained. It matters not thet these are honorable gentlemen, and that they have not heretofore abused these trusts and powers, the anomaly otill exists, and will exist until Congress legislates in the manner prescribed by the legislature of Kentucky in the year 1842.1

It is interesting to note in connection with this controversy over the indebtedness of the cansl company, that Mr. James Guthrie, who was secretary of the Treasury during the administration of Franklin Plerce from 1853 to 1857 , and who cooperated so smoothly with the canal company in many communications and affairs during this period, should in 1867 be corresponding with the United States government as president of the canal company, and in defense of its policies. In fact, $M r$. Guthrie attacks the policy of the Honorable Howard Cobb. his successor as Secretary of the Treasury, who in 1858 placed his interdict upon eng further appropriation of the canal revenues in reference to a branch canal.

2. House Document, op. cit., p. 38. 
From the material contained in this chapter we can see the uncertainty ond indecision which affected the business dealings and management of the canal company during the period from 1855 to 1867 . However, in spite of all this, the canal managed to do quite good derl of business, as is shown in the following table: 1

\begin{tabular}{|c|c|c|c|c|}
\hline Year & $\begin{array}{l}\text { No. of steam- } \\
\text { boats passed. }\end{array}$ & $\begin{array}{l}\text { No.of other } \\
\text { boats passed. }\end{array}$ & Tonnage & To11. \\
\hline $\begin{array}{l}1855 \\
1856 \\
1857 \\
1858 \\
1859 \\
1860 \\
1861 * \\
1862 \\
1863 \\
1864 \\
1865 \\
1866 \\
1867 \\
\text { Total }\end{array}$ & $\begin{array}{r}1,232 \\
1,002 \\
1,419 \\
1,079 \\
1,281 \\
1,620 \\
551 \\
731 \\
1,223 \\
1,014 \\
1,007 \\
891 \\
243 \\
13,193\end{array}$ & $\begin{array}{r}615 \\
506 \\
740 \\
529 \\
592 \\
1,299 \\
329 \\
436 \\
1,064 \\
976 \\
832 \\
1,393 \\
556 \\
9.867\end{array}$ & $\begin{array}{r}355,190 \\
232,780 \\
338,669 \\
249,360 \\
285,305 \\
340,898 \\
134,382 \\
140,699 \\
242,415 \\
247,686 \\
239,347 \\
234,323 \\
68,715 \\
3,109,669\end{array}$ & $\begin{array}{r}94,356.19 \\
75,791.85 \\
110,015.88 \\
75,479.81 \\
90,905.63 \\
131,917.15 \\
42,650.08 \\
69,936.90 \\
152,937.08 \\
164,476.86 \\
175,515.49 \\
180,925.40 \\
54,399.10\end{array}$ \\
\hline
\end{tabular}

*. House Document, op. C1t., pp. 35-36. In the year 1861, 26 steamboats and 118 other boats included in the above) in the service of the government passed toll free. 


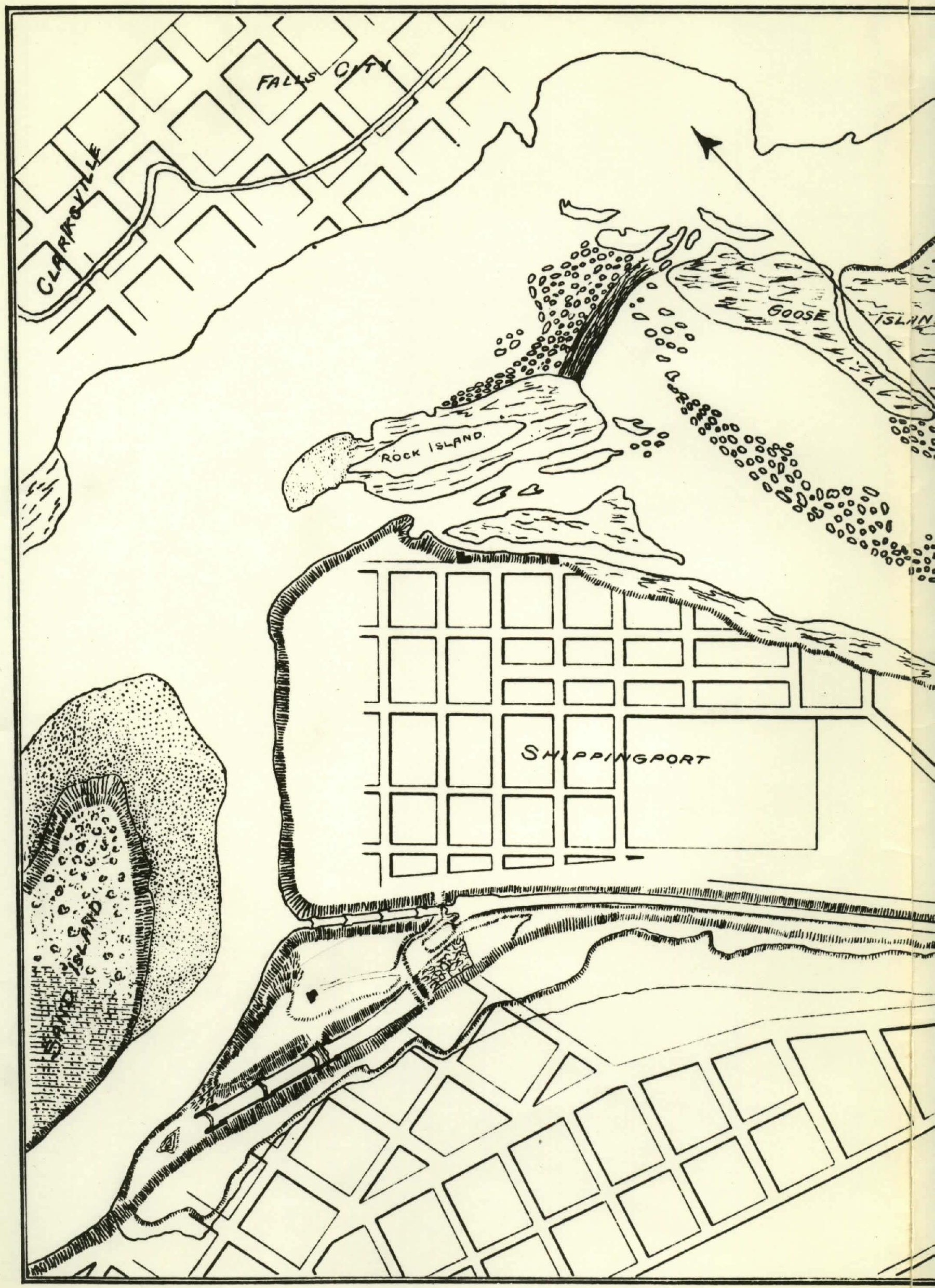




\section{OUTLINE SKETCH}

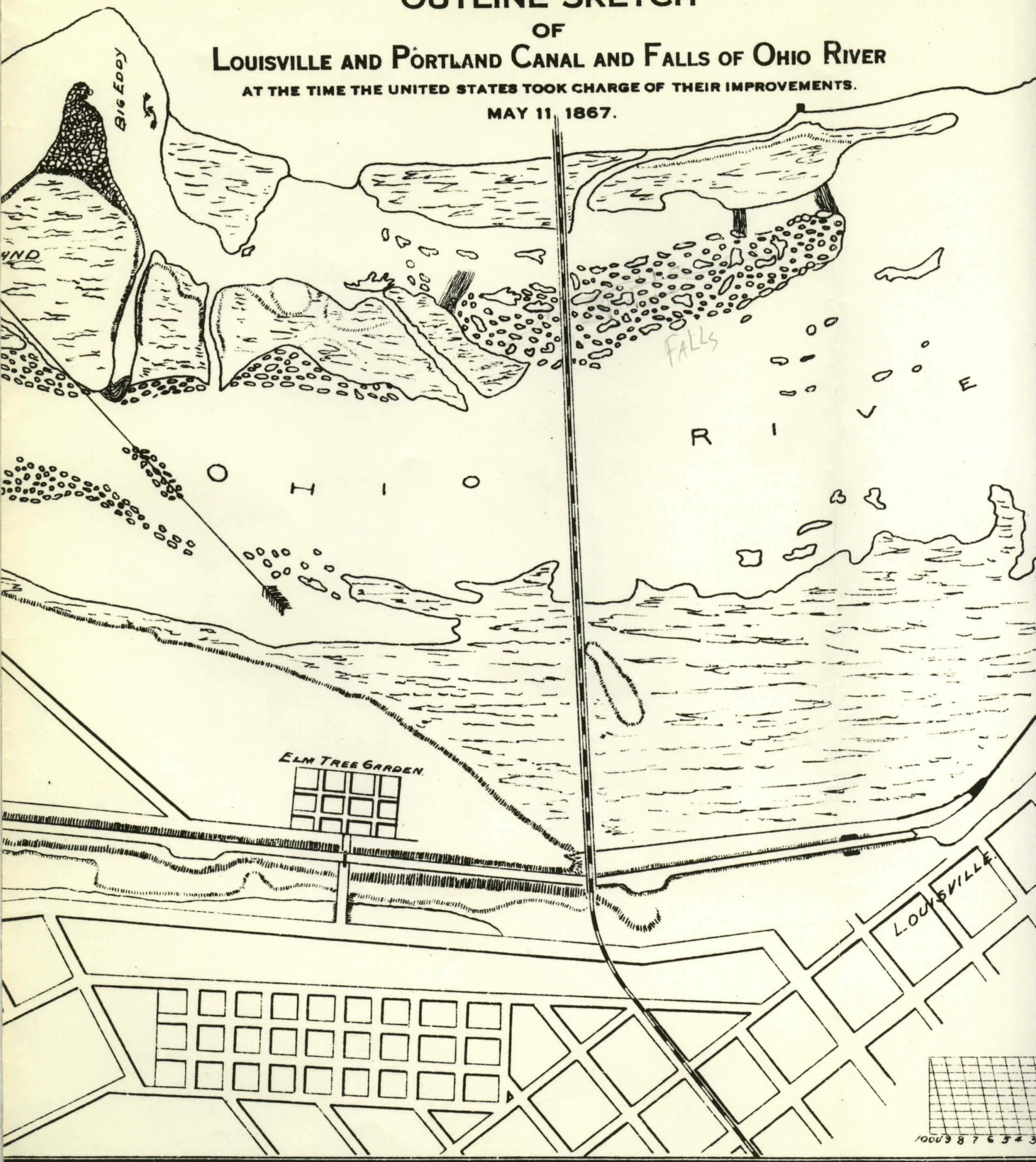




\section{OUTLINE SKETCH \\ OF}

ad Pórtland Canal and Falls of Ohio River HE UNITED STATES TOOK GHARGE OF THEIR IMPROVEMENTS.

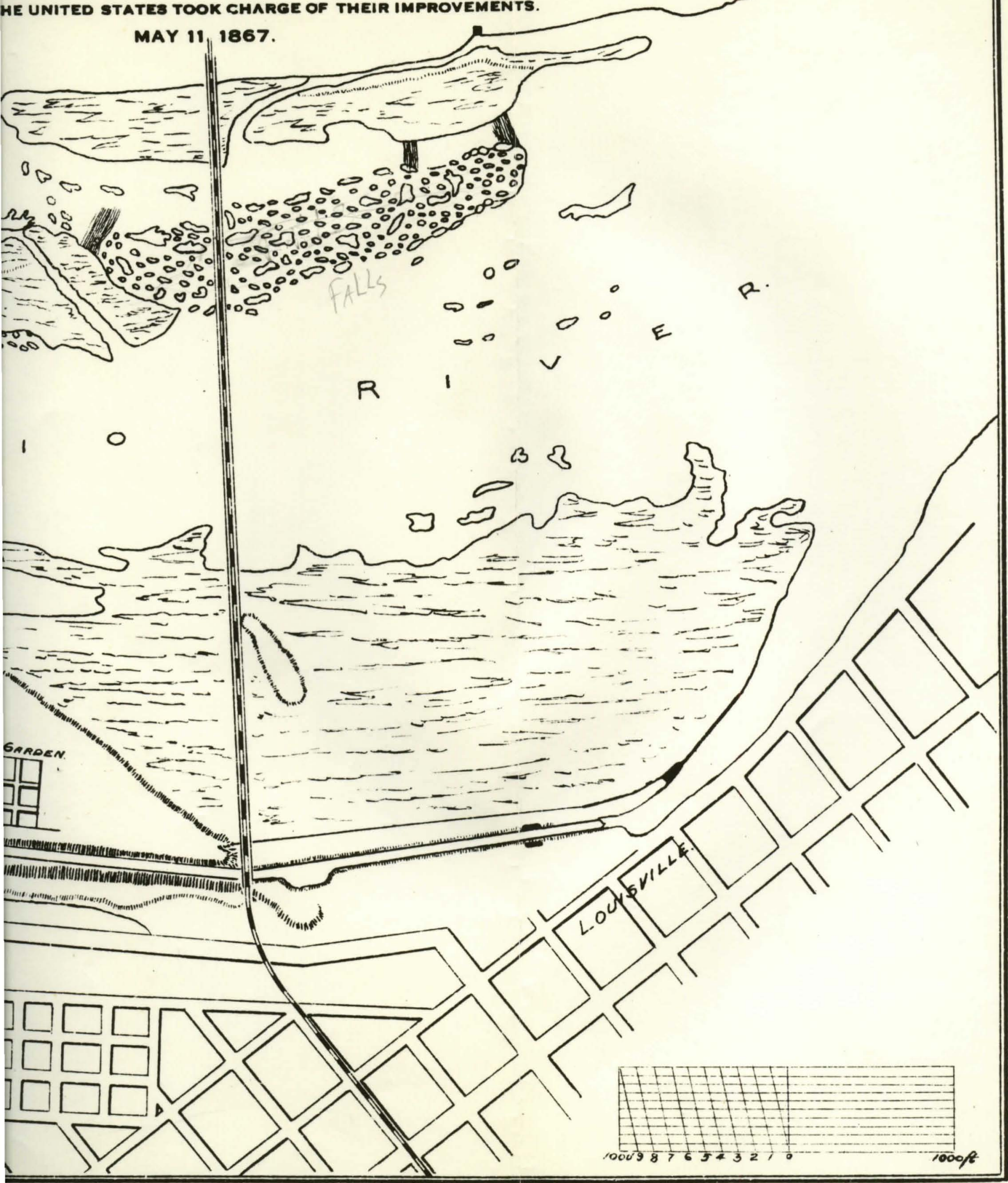




\section{CHAPTER V}

From March, 1867, when a joint resolution of the Congress of the United States provided for a survey of the Falls of the Ohio, to July 1, 1880, when the Iouisville and Portiand Canal was made toll free by the Congress of the United Stater, 


\section{CHAPTER V}

Frow March, 1867, when a joint resolution of the congress of the United States provided for a survey of the Falis of the Ohio, to July 1, 1880, when the Louisville and Portland Canal was made toll Pree by the congress of the United States.

On March 29, 1867, Congress passed "joint resolution providing for the necossary survejs for a ship canal around the Falls of the Ohio River, for military, naval, and commercial purposes." It authorized and directed the Secretary of war to ceuse aurveys, with plans and estimates of cost, to be made by an officer of Engineers, for a ship-canal around the Falls of the Ohio River, on the Indiana side thereof, of suitable location and dimensions, for military, naval, and commercial purposea, and also to cause said offlcer to estimete the expense of completing the Louisilile and Portland Canal, on the Kentucky aide of said falls, according to the plan on which the said company was then progressing with said work.l

Accordingly, Major G. Weitzel of the United Stater Army Engineers was charged with the execution of the work. He was furnished with coples of all

1. tawg of the United Stateg, op. c1t., V.I, p. 16\%. 
previous reports on the subject, but with the understanding that the information contained in them should not supersede the surveys required by the joint resolution.

Operations were commenced in July, 1867, and a remarkably favorable season was had for the work. The Indiana side, the river bed, and the Iouisville and Portland canal and vicintty wero surveyed in that order. While these operations were in progress, all the information available was obtalnod in order to determine the proper dimensions for a canal which would be suitable for commercial purposes, with the assumption that such a canal would, at the same timo, be suitable for military and naval purposes. Two different opinions were found on this subject; some belleving that looks the alze of the new ones on the Loufoville and Portland conal extension. which were three hundred and fifty feet long and eighty feet wide, would be large enough, because, in the future, no more boats larger than these dimensions would be bullt, and that the bulk of the carrying trade on the river would be done by barges, drawn by twoboats. 
Many of the practioal steam boat men, however, were of the opinion that the locks of a new oanal should be larger, contending that the future of the carrying trade would be either by boats built very wide, so as to carry a heavy load with a light draught of water, or in fleets of barges, drawn by tow-boats; so that, in either case, the locks must be large to accomodate the large boat, or to take in at a time the whole tow, and thus sare the time and expense of breaking up a tor to get through the canal and putting it together again below. Besides, they said that the sise of the canal fixes the size of the boats, and if the locks were larger the boats would be built larger, because, up to a cortain limit, a larger boat can make a trip in shorter time, with a larger load, than a smaller boat, and with equal expenditure. ${ }^{1}$

Major Weitzel was of the opinion that the locks of the new canal should be at least one hundred feet wide and four hundred feet long. The oanal itself should be one hundred and twenty feet wide, and should have six feet of water over the mitre aill of the guard gate at the lowest stage. 2

\footnotetext{
1. There were, at that time, at least tro boats running on the river that could not be passed through the new locks of the oanal extension.

2. Exeoutire Document No. 181, 40th Congress, 2nd Session, p. 6 .
} 
As mentioned in the previous chapter, during the progress of the work on the canal extension, as the price of labor and material rose, on account of the recent Civil War, the directors, with a laudable desire to build at least a "working" canal with the means at their disposal, compelled the engineer to make sereral changes in his plans, the most important of which was reducing the width of the canel to 90 feet. According to Major Heitzel, considering the width of the locks, this was a good change.

To report how much more money would be necessary to complete the branch of the louisville and Portland canal, was one of the duties assigned the Mejor by the joint resolution. Accordingly, he reported that to complete the work as modified by the directors would cost $\$ 1,178,000$. To complete it according to the original plan would cost $\$ 1,294,000$, and to complete it as he thought it should be, with the river bank raised to a plane of four feet higher then the highest known flood, and a fall of one foot per mile, would cost $\$ 1,394,000$.

In order to understand positively on what terms the government could get the ownership of the canal, Mejor Weitzel addressed a letter on the 13th 
of December, 1867, to the president of the company, the Honorable James Guthrie, to which he recelved the following reply:

The president and directors of the Louisville and Portland canal Company have to say that they consider themselves as trustees of the stockholders of the compeny; the objects of the trust being to cause said oanal to be so enlarged and improved as to make it sufficient for the requirements of the commerce of the Ohio river, and finally to make it a freo canal; and that having no personal objects to subserve, they would willingly surrender to the government of the United States all the rights, privileges, assets, etc., of the company, provided the government shall purchase the five shares of stock which they hold, and assume the indebtedness of the company incurred in the prosecution of the canal enlargement, and also assume the duties of the trust which they hold to be the completion of sald work of enlargement, as contemplated.

The bonded indebtedness of the company is as follows:

370 bonds due in 1871.........\$370,000

399 bonds due in $1876 \ldots \ldots \ldots \ldots . . .399,000$

398 bonds due in $1881 \ldots \ldots \ldots \ldots \ldots 398,000$

400 bonds due in $1886 \ldots \ldots \ldots .4400,000$

$\$ 1,567,000$

The five sheres of stock are $\$ 100$ each.

There is on hand, to the oredit of the sinking fund, a balence of $\$ 217,453.70$.

Very respectfully,

James Guthrie, Pres. J. H. Roher, Sec'ty. 
Major Weitzel concluded his report on the canal with an appeal to the government to take over and complete this important work as soon as possible. He said that

the amount, in adition to the oash the company has on hand, required to be appropriated to make this a complete and perfect canal, would be $\$ 1,174,000$, and $\$ 1,567,000$ in bonds bearing a six per cent currenoy intereat, a less rate than any public security at the present time bears.

In pointing out thet the western part of the United States deserved the expenditure of the amount of money called for to complete the work, the Mafor continued:

The Ohto River with its branches draing the whole of parts of ten States of the Union; emong them the wealthiest and most populous. It is one of the most important in a system giving 18,000 miles of nevigable rivers.

The states lying on the banks of the ohio and Mississippi rivers, fourteen in number, had, by the census of 1860 , a population of $16,909,494$, or more than half the entire population of the United Stater.

These rivers drain an area $1,785,267$ square miles, more than half of the square miles in the United States, and the valuation of property in these states shows one-half of the valuation of the United States; showing very conclusively that these states pay more than half the taxes, work more than half on 
the improved land, have the majority of the population, and also the majority of the land to derelop, of the whole united Strter.

The proportion of the whole product afforded by these fourteen states we speak for may be judged by the returns of their produce gathered from the census of 1860 , and compared with the whole United States, as follows:

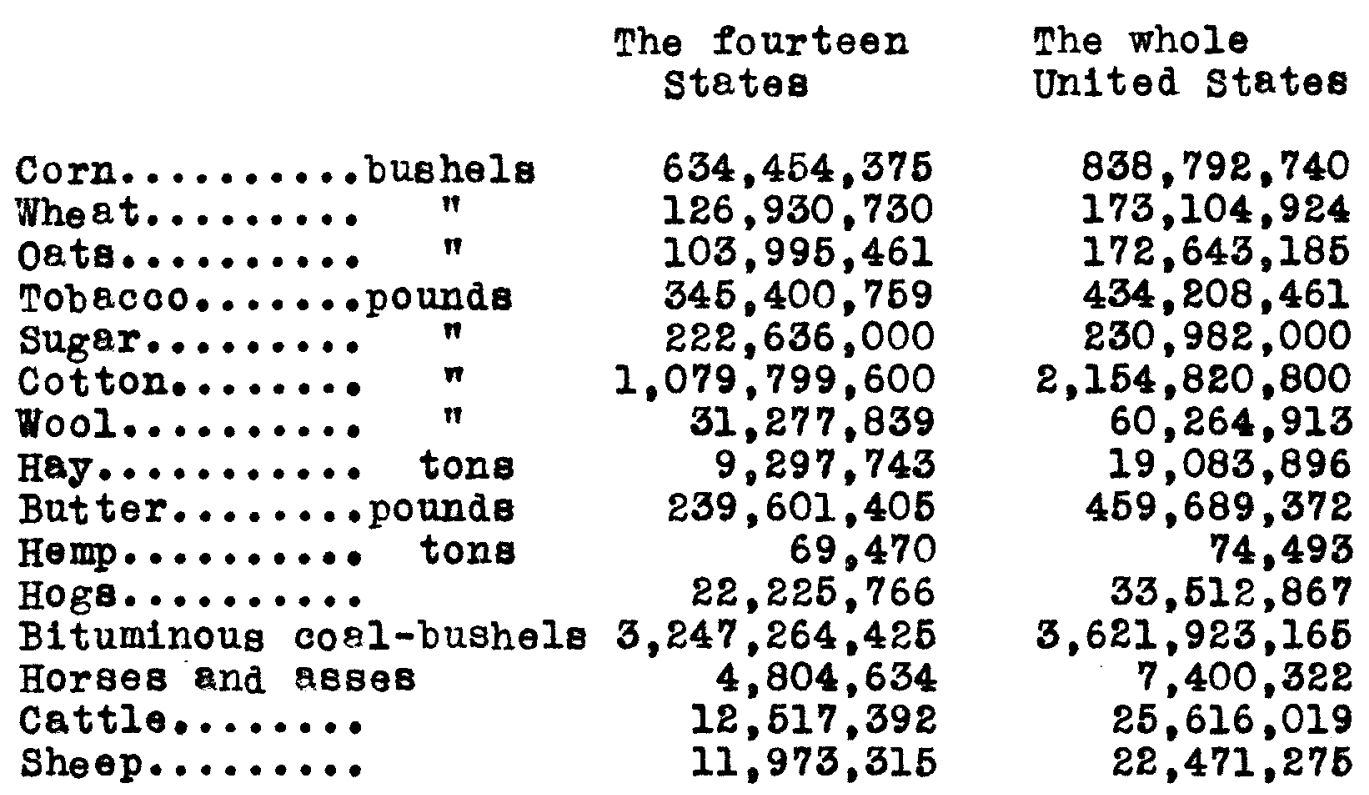

Showing for the river states a great preponderance in the products of the whole country.

If these statistics are not suffiolent, I will add that it too often happens, as it did last fall, that the people along the greater part of these rivers have to pay fifty cents, or more, a bushel for coal, when, with en improved river it would only be worth sixteen cents; thet many thousands suffer cold, and many are thrown out of employment by manufacturers stopping for want, or the high price, of cosl, and that many thousand men engaged in the river trade are annually thrown out of employment because this river is not improved. I am confident that the amount of money annually lost in this way to the people along these rivers would pay the interest on the sum required to do the work, and have so large a surplus for a sinking fund, as in a few years, would eliminate the whole amount. I 
On July 25, 1868, an appropriation of $\$ 85,000$ was made by Congress for improvements at the folls of the Ohio. The Chiof of Engineers, by letter dated July 31, 1868, informed Weitzel that this sum was available for expenditure during that working season, if practicable, towards the construction of the two dams proposed by him for the improvement of the fall of the Ohio, and Woitzol was directed to procesd at once to oarry out the work thus provided for. "If it were essentiel to expedite the work, ho might do it by hired labor and purohese of materiel in open market, and also use the telegraph."

On August 27, 1868, the Chief of Engineers wrote approving Weitzel's recommendation that a cribdam be substituted for the one of masonry proposed to be bullt across the crest of the falle of the Ohio. Weitzel was cautioned to bear in mind that, insemuch as the act of 1868 provided that none of the expenditures should be applied to any works not mentioned in a previous bill of June, 1868, no portion of the allotment could be expended on the Indiane aide of the river, or in view of such work at any future day, but was solely applicable to work incident to the extension of the Louisvilie and Portland canal. 
In his annual report for the fiscal year ending June 30,1869 , Weitzel seys:

I made no arrangement to commence work on the lower dam, because the amount of money allotted would not allow 1t, and also because its construction before the actual extension of the Iouisville and Portland Canal would be very injudicious. The construction of the upper dem before such extension is completed will be an obstruotion to navigation at certain stages for boets too large to pass through the old locks, which are still in use, and is another reason, in addition to the very many already given by me in my previous reports, and by officers who have treated this subject before me, why the proper amount of money necessary to enlarge the body of the old cenel, and complete the branch to the new locks, should at once be appropriated.I

A letter from the Chief of Engineers, of

May 12, 1869, Informed Weitzel that $\$ 180,000$ additional had been allotted by the Secretary of War to the improvement of the falls of the ohio, under the act of April 10, 1869, and that there was no restriction in the manner in which the appropriation was to be exponded.

He was subsequently informed that i per cent of this allottment had been deducted, leaving $\$ 178,200$. Weitzel therefore said in his annual report abovo quoted:

1. Roport of the Chlof of Englneorg, U.S.Army, 1869, 
I had already come to the conclusion, long before recoiving this authority, and I was sustained in my conclusions by the great experience of the directors of the Loulavilie and Portland Canal, that the most important thing was first to enlarge and 1 mprove the entrance to the head of the canal as far as the upper guardgates, and whaterer balance there might be left to omploy in opening the new locks into the main trunk of the conal.

It seoms that after the first allotment was made, it occurred to the authorities in washington that under an organic law of the United Stater, none of it could be legally expended on the canal, because the canal had not been purchased, nor had the legislature of Kentucky ceded unconditional jurisdiction. After the act of April 10, 1869, was passed, the Chief of Engineers, General Humphrejs, in order to secure a portion of it for this work, addressed a letter to General John A. Rawling, Secretary of War. After presenting the claim of this work for a portion of the appropriation, he saye:

After a oareful examination and consideration of the whole subject. I am decidedig of the opinion that an allotment of some portion of the recent appropriation for rivers and harbore to the enlergement of the canal may be properly mede, and I therefore recommend 1t. 1 
This letter and the whole subject were considered and disoussed in Cabinet meoting, and General Humphrey's opinion was approved and adopted by the Administration. Thus a danger which seemed at one time to threaten the very life of the work at the start, was remored,

In the summer of 1869 the merchants, manufacturers, and steamboat owners of the ohio ralley, seeing the slow progrese of the work, owing to the amall amounts allotted to it, again took hold of this matter with "great earnestnese and determination." As a result of their efforts, the Aivers and Harbon fat of July 11, 1870, appropriated $\$ 250,000$ for 1t. By joining hands with those interested in the commerce of the Upper Mesissippi, a special act appropriating $\$ 200,000$ was passed at the next session, and approved January 18, 1871. The Rivers and Harbors Act of March 3, 1871, appropriated $\$ 250,000$. With the sums thus allotted and appropriated, the work was pushed as vigorously as possible, and on February 26, 1872, the new locks were opened to $\operatorname{commerce}$, and the largest class of boats could pass through the canal. A great deal, however, remained to be done to complete 
it according to Mafor Weitzel's original plans. on March 28, 1872, the following joint resolution was passed by the Kentucky legisleture:

Whereas all the stock in the Loulsvillo and Portlend Canal belongs to the United States Government except five shares owned by the directors of the compeny, and said directors, under the avthority of the legieleture of Kentucky and the United States, executed a mortgage to secure bonds named in said mortgage, some of which are out and unpaid, and said canal company may owe other debta; and

Whereas it is right and proper that the Government of the United States should assume the control and menagement of said canal: Therefore be it

Resolved by the general assembly of Kentucky, That the president and directors of the Loufsille and Portland Canal Company are hereby authorized and directed to surrender the said canal and all the property connected therewith to the Government of the United States, upon the following terms and conditions:

1. That the Government of the United States shall not levy tolls on sald canal, except such as shall be necessary to keep the samo in repair, pry all necessery superintendence, cus tody, and expenses, and make all neceseary improvements.

2. That the city of Iouigville shall have the right to throw bridges over the canel at such points as said city shall deem proper: Provided always, That sald bridgea shall bo so located as not to interfere with the use of the canal, and so constructed as not to interfere with its navigation. 
3. Thet the title and possession of the United States of seid canel shall not interfere with the right of the state to serve criminal and civil processes, or with the state's general police power over the territory covered by said oenal end its eppendages.

4. And further, thet the city of Iouisville shall at all times heve the right of drainage into sald canal: Provided, That the connections between the drains and the canal shall be made upon the plan to keep out mud and garbage.

5. That the use of the water power of the canal shall be guaranteed forever to the actual owners of the property contiguous to said cenel, its branches and dems. subject to such restrictions and regulam tions as may be mede by the secretary of the Department of the United States Government which may have charge of said canal.

6. That the Government of the United States shell, before such surrender, discharge all the debts due by said canal compepy, and purchase the stock of said directors.

The Rivers and Harbors Act of June 10, 1872 appropriated $\$ 300,000$ for continuing the work, and directed the Secretary of War to report to congress at its next session, or sooner, if practicable, the condition of the canal, and the provisions nocessary to relieve the same from incumbrance, with a view to such legislation es would render the same 
Iree to commerce at the earliest practicable period, subject only to such tolls as may be necessary for the superintendence and repair thereof, "which shall not, efter the passage of this act, excerd five conts por ton."

By letter from the Chief of Engineers, June 19, 1872, Major Woitzel was directed to give official notice to the president and directors of the canal company of the provisions of the last clause of this 1tem, relating to tolls. This he did, and received a reply from Mr. J. F. Speod, president of the company, dated June 27, 1872, that the company would do nothing that might be construed into an acknowledgment that the government could fix the rate of tolls for the use of the canal until the joint resolution of the Kentucky legialatare, approved March, 1872, had been complied with by the United Statea; that the company had been advised that a permission to expend the $\$ 300,000$ appropriated by the ebove item in continuing the work on the canal might be regarded a an acknowledgment of a right in the government to fix the tolls at five cente per ton, and that therefore justioe to the creditors of the company and duty to the state compelied them to decline the appropriation 
and refuse the use of the canal for its expenditure. Mr. Speed subsequently wrote, in reply to another letter from Major Weitzel, that the whole appropriation was declined, and that no part of it could be expended on any property of the company. Previous to this time, stetes weitzel, the directors and he had worked in perfeot hermony. They had always mot all of his requests with courtesy, and had granted them as speedily as the duties of their trust would warrant.

This matter resulted in a lengthy period of correspondence between Weitzel and the president of the canal company. Weitzel determined to go on with the work under the appropriation, and requested that the district attorney (COI. G. C. Wharton) be ordered to act as his counsel, and prevent the directors from interfering.

Through the good sense of the Honorable James Speed, says Weitzel, the counsel for the direotors, Colonel Wharton, and their associate counsel, it was agreed, after a little preliminary legal skirmishing, to bring the c8.8e at once before a judge of the Supreme court of the united states for decision. The case was tried before Associate Justice Miller, of 
the United States supreme court. He granted an infunotion preventing the directors from interfering with the work, but decided that the directore alone, at that time, had the power of regulating the tolls. This judioial action was satisfactory to all, and removed another danger which threatened the completion of the work. ${ }^{1}$

The Rivers and Harborsact of March 3, 1873 , appropriated $\$ 100,000$ for the completion of the canal, and the Secretary of the Ireasury was authorised and directed to assume, on the behalf of the united Stater, the control and mangement of sald canal, in conformity with the terme of the joint resolution of the legisloture of the state of Kentucky of March 28, 1872, at such timo, and in such monner 8s, in his judgment, the interests of the United states and the commerce thereof might require; and the sum of money necessary to enable the secretary of the Treasury to carry this provision into effect was appropriated. This item also contained a proviso thet when the United States assumed control of the canel the tolls thereon should be reduced on ressels propelled by steam to 25 cents per ton, and on all other vessels in proportion.2 2. Lawg of the United states, op. cit., V.I, p. 215. 
The folnt resolution of the Kentraky Iegislature of March 28, 1872, above referred to, and given in full on pages elght and nine of thie chapter, was passed at the instance of partio interested in the western commerce. Its obfect was to enable the government to make the canal free by assuming the debt without being compelled to awalt the time when the enlargement was completed. The following act providing for the payment of the bonds of the Louieville and portiand canal Company and taking control of the canal, was passed by Congress at its next session, and approved sey 11 , 1874:

Be it enacted by the Senate and House of Representatives of the United States of America in Congress assembled, That the appropriations made by the act approved March 3, 1873, entitled "An act making appropriations for the repair, preservation, and completion of certain pubilc works on rivers and harbors, and for other purposes," for the peyment of the debts of the Loulsville and Portland Canal company, are hereby continued in full force, and are made permanently applicable to the payment of the debta of the said Louisvilio and Portland Canal Company; and so much as may bo necessary shall bo applied to the payment of the interest as it accrues, and the principal of the outstending bonds of said company as they mature: Provided however, That the Secretary of the Treasury may purchase and pay for any of said bonds at 
the market price, not above par, whenever he deems it for the interest of the United States.

Sec. 2. That after thirty days from the passage of this act the Secretary of war is hereby authorized and directed to take possession of the said Louistille and Portland Cenal, and all the property, real and personal, of said company, as provided for by the legislature of Kentucky........ Jurisalction by the United States shall bo subject to the mortgage lien on said property. and the holders of the bonds issued under it... The Secretary of the Treasury is authorized to pay the directors of said company for the stock held by them..... and seid Secretary is directed to give public notice in sich a manner as will best effect the purpose, to all persons and corporations having debts of any nature ageinst the canal company. except the bonded debt thereof, to present them to him on or before the first day of July, 1875.

Section three of the act provided for the abolishment of all tolls except those necessery for current expenses, and repair, and for the year 1874, they were set at ten cents per ton on steambocts, and 1ve cents per ton on others. The secretary of the Treasury was made responsible for reporting the affairs of the canal.

Section four la id down specific actions which were to be taken if at any time it became necessary to enforce the lien of the mortgege on the canal property for the benefit of the bondholders. I 
In accordance with the provisions of the

above act, the War Department issued a special order, of which the following is a copy:

To carry out the provisions of the second and third sections of the act of Congress approved Mey 11, 1874, "providing for the payment of the bonds of the Louisville and Portland Canel Company," Major Godfrey Weitzel, Corps of Engineers, is appointed to proceed to Louisville, Kentucky, and confer with the president and directors of said company, with a view to making the necessary arrangements for receiving and taking possession of the canal" and all the property, real and personal, of said company, the property of the United states."

Major Weitzel is empowered to agree with the canal compeny upon some day subsequent to the thirty days named in the act for the transfer of the canal to the United States, and is authorized to take cherge of the same when it shall have been delivered into the possession of the United States. He will state what employees are necessary for the carrying on properly of the operations of the canal within the provisions of the act, and will also report at an early day the result of his conference with the canal company, and submit to the Chief of Engineers, for the approvel of the seoretary of Wer, such recommendations and suggestions as may in his judgment be necessary to a proper execution of the provisions of the act and to the protection of the interests of all concerned. He is also authorized to employ, temporar1ly, such persons as mey be necossary, in order to avold any interruption of or obstruction to the business of the canal. 1

1. Engineers Report of January 1, 1875, p. T7\%. 
Weitzel reported that on Tuesday the 9 th of June 1874, he met the directors of the Iouisville and Portland Canal at thoir office in Loulsvillo, Kentucky, and that after a brief conference it was agreod that an inventory of property should be taken by the representatives of the United statea and their company, and the invoices and receipts should be signed on the following day and the transfer made, to take place at the earliest moment the law allowed 1.e., Wednesday night, midnight.

This was done, and on Thursday morning, shortly after midnight, the first boat pessed through under the rates of toll prescribed by the new law, and thus was accomplished a thing which the people of the West had been endearouring to effect during the preceding thirty-four years. ${ }^{l}$

The Rivers and Harbors Act of March 3, 1875 , appropriated $\$ 100,000$ to complete the canal according to the original project of Major Weitzel.

In March, 1876, Captain Mackenzie of the Engineer's office at Louisilile reported that the canal management had had much trouble within the last few days with tows, and that several unnecessary

1. Enginears Report of January 1,1875, p. 778 . 
delays had been the consequence. The regulations of the canal and the orders of the superintendent had been violated, and there was no way to prevent recurrences of the same state of affairs under the existing rules and regulations. Tow-boats frequently, after having brought the ir tows to the locks, would run back and go over the falls, thereby causing much delay and trouble. In order to remedy the situation, captain Mackenzio recommended that the following changes be made in the rates of tolls:

1. Steamboats bringing tows to the locks and leaving them for the purpose of running over the falle and taking charge of tows below the locks, shall be charged the same rate for using the canal as if they had nassed through the locks.

2. For moving flate, boats, etc., through locks, $\$ 5$ per bost in addition to the tolla. These charges are exceedingly just, and are recommended for the purpose of compeliling steamboats to remein with their tows and propide sufficient crew for managing them.

The recomendation for a change in the tolla was approved by the Secretary of Wer.

on February 27,1880 , the House Commlttee on Railways and canals, to whom was referred a bill

1. Executive Document, No. 43, 44 th Congress, Ist Session, p. 1. 
to abolish all tolls on the Loulsville and Portland

Canal, having had the same under consideration, reported as follows:

The Louisville and Portland Canal is the connecting link in the great chain of commerce between the cities of Now York, Philadelphia, Baltimore, and other places east of the Alleghrnies, and the oities of Pittsburgh, Wheeling, Cincinnati, Louistille, Saint Louis, and other important points west and northwest of the Appalachian Range. It is the lock and key to the whole system of river navigation from the head-waters of the Ohio to the Gulf of Mexico. Over three thousand boets and barges pass through its locks in the descending and ascending navigation of the ohio River. The number of tons carried by these boets during the past year was 999,610. This Immenee tonnage will, it is belleved, in the near future attain even more gigantio proportions.

Up to the 1lth of June, 1874, the tollage paid by all vessels propelled by steam was fifty cents per ton. From the year 1831, when the canal was first opened for business, to 1872, the tolls received at this point emounted to $\$ 5,157,247$. Since the government assumed control the tolls have been reduced to onefifth of the former amount. But, even with this reduction, over $\$ 300,000$ has been collected, thus swelling the grand total which the producers and shippers of twelve or fourteen states of our country have paid to pass an obstruction of less than two miles on one of our national highways to over five and one-half millions of dollars.

The bill under consideration proposes that at the close of the present fiscal year, the tolls now collected by the government shall cease. Your committee report thet such e result is in accord with the spirit, if not the letter, of former treaties and legislation both by the state 
of Kentucky, and by the United States. The treaty of paris, negotiated in 1783; the treaty with Spein, negotieted in 1795; the ordinence of 1797, and meny subsequent acts of Congress, provide for the absolute freedom of the Mississippi River and its tributaries, and dedicate them to the world as great national highways, to be kept forever free from any toll, tax, or duty of any kind whatever.

These various treaties, reports, acts, and officiel declarations indicate that for nearly half a century it has been the desire and intent of the government to secure the free nevigetion of the ohio at this point. But whatever be the meaning of former treaties and resolutions, your oommittee ere of the opinion that the time hes now arrived when. as a matter of right as well as of policy. every restriction or tax should be removed, and this canal be declared free to the wholo world.

The "right of way," once said a great statesman, "Is the right of the miliion."

The sovereign holds it in trust, and can exercise it only for their benefit, and has no right to make a revenue, or permit a revenue to be made out of it. Such a course must engender the worst oppression and the woret corruptions, and soon realize the view of the worst governments--taxation on all we consume--which will sllow nothing to go to or from the markets without tribute to the state.

Your committee find thet in every other instance except the Louisville and portland Canal, this great popular right has been recognized and respected. At the Eado jettiea, at the harbor of New York, at the canal uniting the upper and lower rapias of the Mississippi River, and at various other points, vast sums of money, amounting to 
hundreds of mililons, heve been expended. From none of these works, of which the government is the sole owner, has any toll or tax ever been demanded, and yet hardy one of them is of more importance, or more national in its character, than this canal.

Your committee see no reason why the people of the Ohio and Mississippi valleys should be deprived of the benefits of that policy which has been so fully pursued, to the advantage of commerce, at every other point in the Union, and therefore report back the bill, and respectfully recommend that it be adopted. 1

As a consequence of the above report,

Congress, on May 18, 1880, passed the following act:

That after the first day of July, 1880 , no tolls shall be charged or collected at the Iouisville and Portiand canal, but the secretary of War shall be authorized to draw his warrant from time to time upon The secretary of the Greasury to pay the actual expenses of operating and keeping said canal in repair.2

During the period from June 11, 1874, when the government took control of the cansl, to midnight July 1, 1880, when all tolls were abolished, the government receipts on the canal amounted to $\$ 417,069.38$, the expenditures to $\$ 386,814.02$, leaving a balance on hand of $\$ 30,255.36$, which was later expended on

1. House of Representetives, Report No. 348, 46 Congress, 2nd session; pp. 1-3.

2. Law of the United Strtes, op. c1t., V.I, p. 306. 
improvements. The largest single work which wa done under this head was to change the old locke from three chambers to two, so that the capacity of these old locks was increased to boata 269 feet 10ng. The cost then of the superintendence, management, and ordinary repair of the canal during the six years and twenty deys while under government control was about $\$ 267,000$, or at the rate of about $\$ 44,000$, per year. The former management had estimated it at $\$ 70,000$ per annum. A little less than one-third of the annual expense of operating the canal was consumed in keoping the canal and locks clear of the mud and silt which high waters deposited in them. 


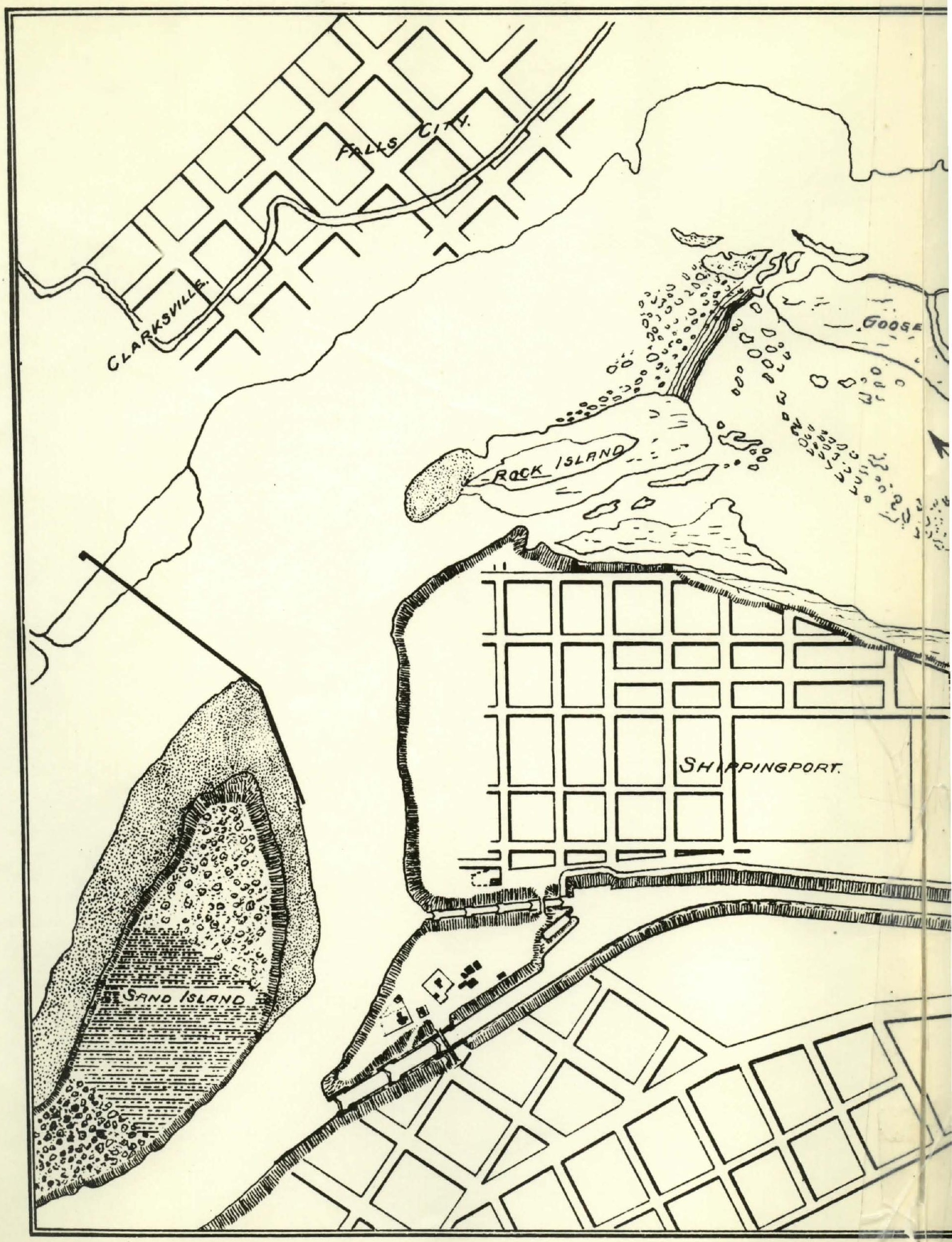




\section{OUTLINE SKETCH}

OF

Louisville and Portland Canal and Falls of Ohio River AT CLOSE OF FISCAL YEAR.

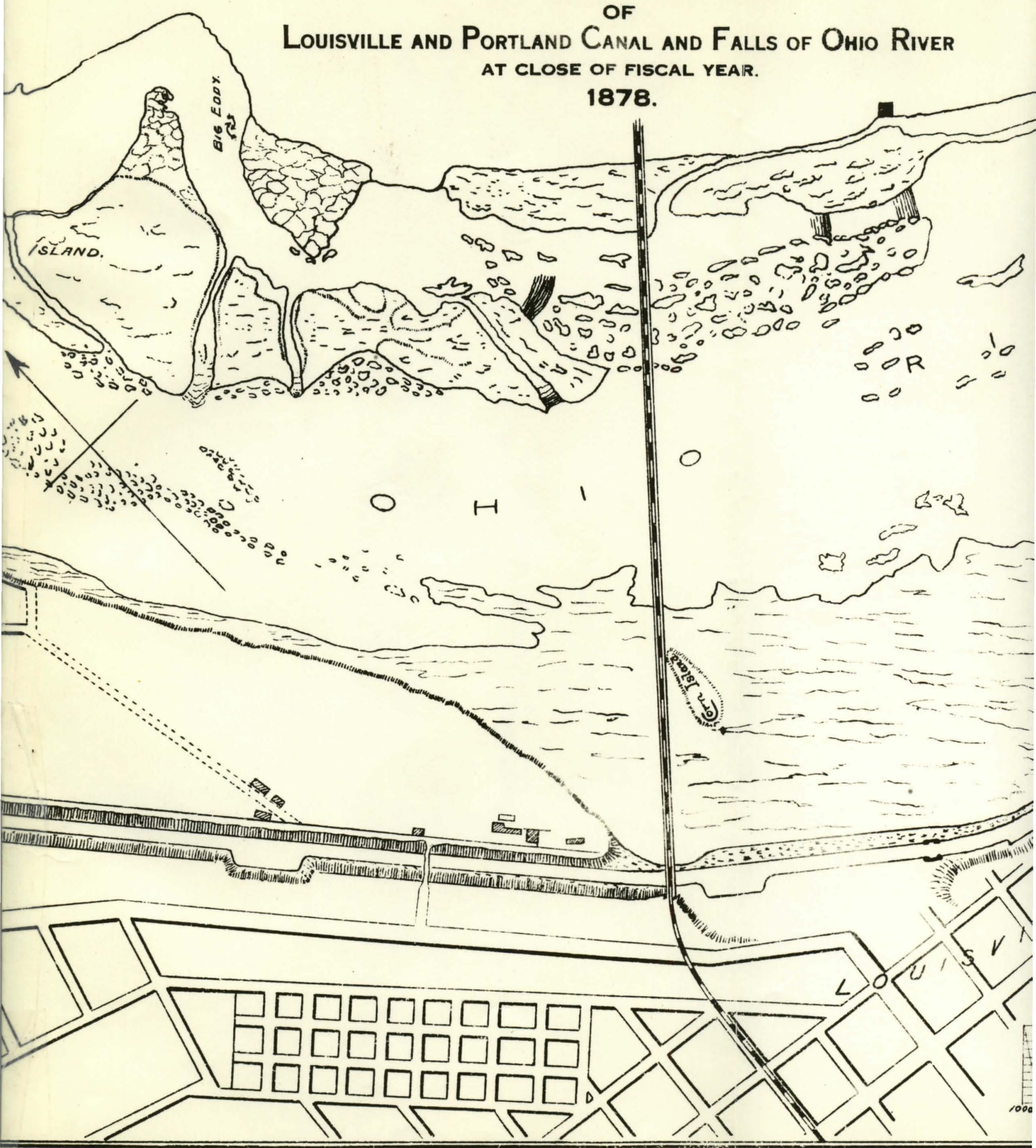


PLATE III

OUTLINE SKETCH

OF

and Portland Canal and Falls of Ohio River AT CLOSE OF FISCAL YEAR. 1878.

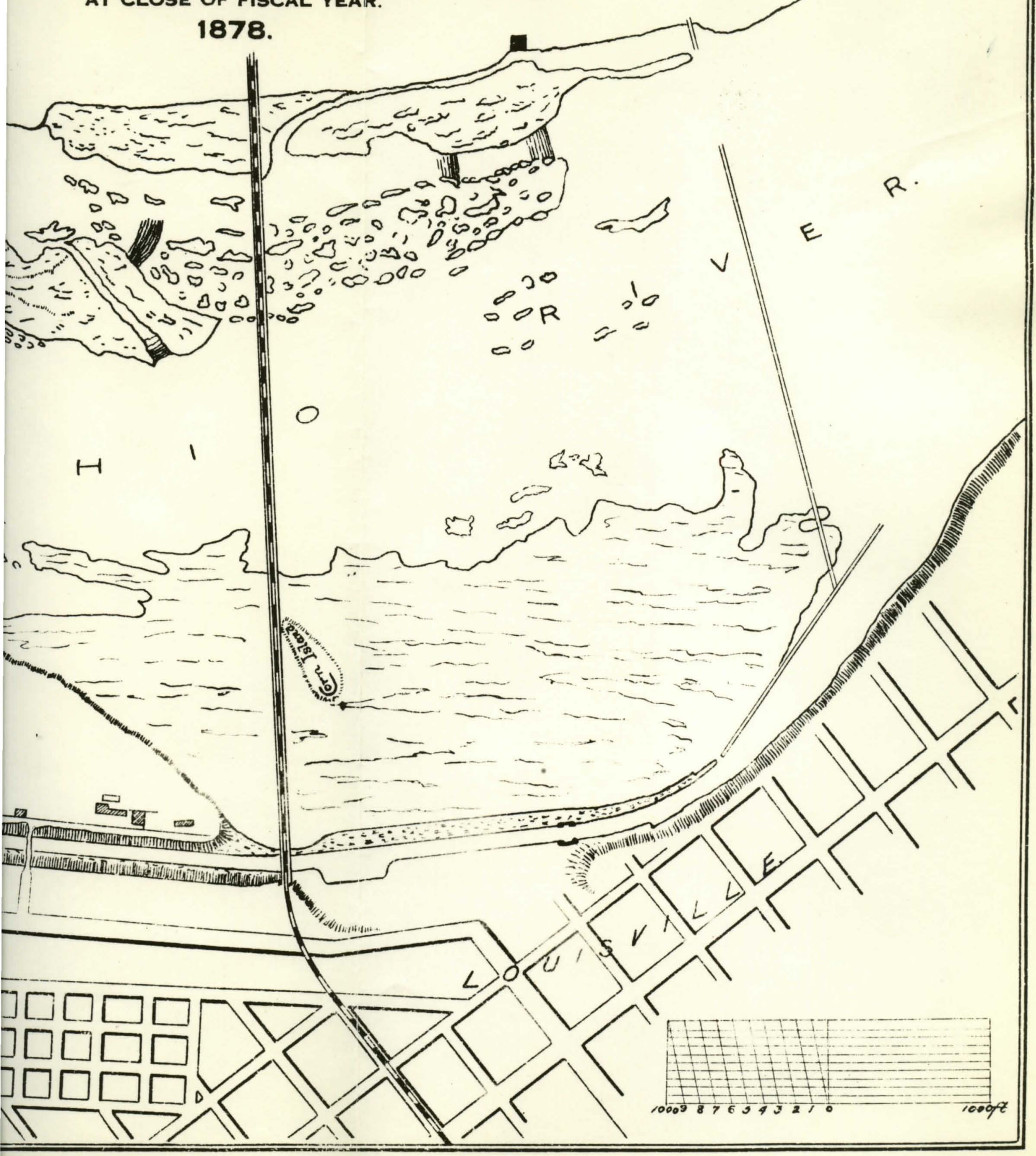




\section{CHAPTER VI}

From 1880 when the canal was made free of tolls, to the present. Including $a$ brief description of the Hydro-slectric Plant. 
CHAPTER VI

From 1880 when the canal was made free of tolls, to the present. Including a brief description of the Hydro-Eleotric Plant.

In July, 1880, shortly after the cand had been made toll free by act of the Congress of the United States, Major H. G. Wright, Chief of Engineers, made a request to the secretary of war for $\$ 5,000$ "for operating and keeping in repair the Louisville and Portland canal." The Major based his request on the concluding part of the act to abolish tolls at the osnal, which gave authority to the secretary of War to draw his warrant from time to time upon the Secretary of the Treasury to pey the actual expenses of operating and keeping said canal in repair. In reply, the secretary of war informed Major Wright that upon an informal inquiry to ascertain the technical title of the appropriation made by the above mentioned act, it had been suggested that the act per se made no appropriation. The secretary further called the Major'attention to the river and harbor b1ll approved June 14, 1880 , which stated that the balance in hand after the 
payment of any existing liability, collected previously as tolls on the Louisville and portland Canal, or which might later be so collected prior to the pessage of an act to make said canal Iree to the public, was thereby authorized to be expended for its improvement. Such expenditure however was not to exceed $\$ 60,000$.

After a good deal of correspondence about the matter, the Secretary of the Ireasury, in August, 1880, addressed a letter to the First Comptroller of the Treasury, asking his opinion as to whother an appropriation was authorized by the aot of May 18, 1880, for operating and keeping in repair the Louisville and Portland Canal. The Comptroller replied that he had considered the subject with great care, and was of the opinion that the act referred to did not make an appropriation for operating and keoping said canal in repair. The comptroller said, in explanation of his deciaion, that if the act made an appropriation at all, it was a "permanent specific appropriation, indefinite as to time, and unlimited as to amount, and as to such appropriations, the rule of 
construction must nooessarily be, that if they exiat by inference at all, the language from which it is drawn must be clear and conclusive. This being essential to preserve the right of Congress to control appropriations. The comptroller then cited the case of Madre vs. Felton, to show that permanent indefinite appropriations, as a general rule, were against the spirit of the constitution. As a conclualng reason ageinst holding that the act of May 18 carried an appropriation, the Comptrolier said that the act of June 14, authorized an expenditure of a certain "balance," limiting it so as not to excerd $\$ 60,000$. This would have been unnecessary if the act of may 18 had made an eppropriation. "It is true," he says, "the act of May 18 is prior in date to that of June 14, and the former evidently was passed in contemplation of an appropriation thereafter to be made, or of that provided for by the act of June 14, which was the first introduced in Congress, and to which that of May 18 referred as supplying the money on which the seoretary of War was to draw his warrant." l

1. Executhro Document No. 17, U. S. Senate, 46th congress, उa seseion, pp: 1-12. 
The comptroller steted that he realized the importance to the interests of commerce thet the canal be kept in repair, but that if unexpectedly, the funds devoted to thet purpose by Congress proved indequete, it was not the province of executive officers to interpose a construction of statutes which might introduce infinite danger by way of precedent in the future.

In Januery, 1882, the Senate of the United States called for a special report on the improvements still needed at the falls of the ohio to serve the Interests of the commerce of the ohio River. Accordingly, the report was de on February 10, 1882, by Major Weitzel, who listed the following projects as work necessery to be done.

(a) About 1,300 feet in length additional of the permanent dam, as designed and partially constructed across the ohio River on the crest of the falls should be converted into movable dams.

(b) The entrance to the head of the canal should be very much enlarged.

(c) Additional canal accommodations around or over these obstructions should be provided.

(a) That portion of the north bank of the existing canal which has thus far been untouched by the work of enlargement should be rectified and new side walls built. 
(e) A set of gates should be provided in the branch canal just above the new locks for high-water lockage.

(f) A new lock should be built with chember as wide as the present new locks.

(8) A new dry-dock should be constructed.

(h) The basin above the head of the present locks should be enlarged.

In giving his reasons why the above improvements should be completed as soon as possible, the Major says:

The Ohio River Basin, according to some bulletins relating to the census of 1880 which I heve been able to seo, st1ll maintains its supremacy over any other portions of the great Mississippi Bacin. It st1il yields enormous quantities of iron, steel, coal, petroleum, wheat, corn, oats, selt, and tobacco, and its numerous manufacturing intereste are on a steady and healthy increase。

The total internal revenue collections for the fiscal year which ended June 30, 1881, was over $\$ 135,000,000$. Of this amount over $\$ 87,500,000$ were collected in the eight States which, wholly or in part, lie in this basin.

No toll has ever been paid on the Des Moines and Rock Island rapids in the Upper Mississippi, and Congress has apnropriated $\$ 5,955,350$ to improve them against $\$ 2,600,000$ expended here.

In order to improve the navigation to Iake Superior, the government in 1852 gave the State of Michigan 750,000 acres of land and 
the right of way to build a canel around the falls of the Seint Mary's River, and has appropriated $\$ 2,616,000$ since for its enlargement and the improvement of the river.

As the work now stands, it is inadequate to serve the interests of the Ohio River, and it w1ll become more and more so each year until the additionel worke suggested by mo are completed.

Delays occur whenever a great number of vessels arrive at the locks at the same time, notwithstanding the fact thet lockage is then carried on day and night. The greatest of these occur on a so-called coal rise; that is, when the river rises sufficiently to liberate large numbers of coal tows at Pittsburgh and below. Since the government has had charge of the canal these coal riges have averaged five in number per annum. The averated time required to lock everything through on such occrsions is about six days. The greatest number of lockages made with the new locks in twenty-four hours has been twenty-one. At each lockage of the new locks from two to three coal boats or six coal barges are passed through. one coel boat or four coal barges are locked through the remodeled old locke at lockage. Aside from the delay of the coal fleets, from eighteen to twenty-four passenger steamers are delayed on such occasions. The average delay to each one has been fourteen and half hours. The average cost of each day's delay to them is $\$ 200$ per steamer.1

In February, 1883, the Ohio Velley was visited by the highest flood ever known, exceeding at Cincinnat1, the historic flood of 1832 by two feet four inche日. It was supposed that this was the

1. Executive Document, No. 129, U. S. Senate, 47th Congress, Ist Session, pp. I-24. 
climax for at least one generation, but in the same month of 1884 the river again overflowed its banka, and at Cincinnati it exceeded the flood of 1833 by over four and one-half feet. ${ }^{1}$

In the year 1886, it was reported to the House of Representatives of the United states, that the engineers in charge of the Louigville and Portland Canal had objected to the right of the city of Louisville to drain its sewers into the canal. Consequently the Secretary of war was directed to report to Congress whether, "in his judgment, seid right of drainage should be conceded to the ofty of Louisville, and, if not, the reason therefor, together with such information upon the subject as might to him seem proper in the premises." The Secretary reported that the city of Louisville based its right to drainage in the canal on a joint resolution passed by the legislature of Kentucky in 1872, in which the president and directors of the Louisville and Portland Canal were directed to surrender the said canal and all the property connected therewith to the Government of the United States, upon certain terms and conditions, one of

1. Report of the Chief of Engineers, 1884, p. 168\%. 
which was nthat the city of Louisville shall at all times have the right of drainage into ald canal: Provided, That the connections between the drains and the canal shall be made upon the plan to keep out mad and garbage."

The secretary of War went on to aay that the Congressional act of May 11, 1874, had directed the secretary of War at that time "to take possession of the said Iouigrille and Portland Canal, and all the property, etc., as provided for by the act of the general assembly of the state of Kentucky, approved Fobruary 22, 1844.....concoding juriodiction over said canal to the United statea....." In thio act the foint resolution of the legislature of Kentuoky of March 28, 1872 is not mentioned, and in its report upon this messure the committes on Finance of the United States, on the 14th of April, 1874. speaks of the conditions contained in this resolution of the Kentucky legisleture as "conditions sought to be imposed for the local advantage of the city of Iouistille."

The Secretery of war then said that "even assuming that the joint resolution of the state of Kentucky of March 28, 1872, which provides that the 
c1ty of Louirville mag drain into the oanal. 18 in force and binding on the United stetes, it cortainly does not confer upon that oity the right to pollute and to render foul the waters of the conal."

Since the city rested its claim to drain Into the canal upon the joint resolution of 1878 alone, and since the United States accepted the oanal under other state legislation, and not under that resolution, the decioion was made, that the resolution of 1872 could have no force in binding the United states. 1

After the year 1880, the improvements at the falls of the ohio included the enlargement of the basin immediately above the locks of the Ioulsville and Portland Canal, the enlargement of the head of the canal, and straightening, deopening, and controlling the water flow in the Indiane chate Channel. The former was completed in 1893.

Previous to 1883, the approach to the canal at its upper end, above the Louisville Bridge Co.'s bridge at Fourteenth Street, was so narrow as to constitute a source of much expensive delay to the

1. Sxecutive Document, No. 51, House of Representatives, 49th Congress, 2nd se8sion, pp. 1-12. 
largo quantity of traffic which came down the river on ordinary riges. The canel proper from Ninth to Fourteenth Streets wes only 100 feet wide and curved between the two points, so that progrese was slow and accidents frequent and unavoidable. The greater part of the dike marking the north aide of the approach to the canal was submerged when the river reached a state of 8.4 feot, upper canal gauge, and at stages of 9 foet or more a strong current set out from the shore, thus oarrying mang vessels against the dike and, at high enough stages, over it onto the rock lodges. This approach was 1,800 leet long and varied in widh from 400 feet at the upper end to 100 feet opposite Ninth street. Its area was wholly insufficient for the required breaking and rearrangement of tows preparatory to entering or leaving the conel.

The original project for the enlargement of the hoad of the canal was adopted in 1883, and proposed the enlargement of the canal, beginning at a point a short distance below the railroad bridge at Fourteenth street and extending eastwardis to the crose dam, so as to not only straighten and widen the canal proper, but also provide ample space for the 
rearrangement of towg about to enter or lease the canal. This was slightly modified in 1885, so far as the location of the new north wall was concerned. A revision of the project was made by a board of engineer officers January 28, 1890, and approved by the Chief of Engineers January 31, 1890. Th1s revision modified the area formerly proposed to be excavated and determined the number and kind of structures, etc., to bo erected. 18 approved, it provided for enlarging the canal on its northerly aide from a point 725 feet below the railroad bridge at Fourteenth Street, where the width of the oanal was abruptly increased from 90 to 210 feet. This latter width is then gradually increased through a distance of nearly 2,800 feet to 325 feet at the head of the canal proper, at which point the enlargement is expended into a capacious basin or harbor 1,200 feet wide, and practically parallel to the Kentucky shore. The structures proposed were a new retaining wall on the north side of the canal. movable dam about 800 feet long, a fixed dam extending from the movable dam at the westerly end of the basin to the south abutment of the movable dam in the Middie Chate opening of the cross dam, the excavation of 
rook within designated limits to the same level as the eanal bottom, the construction of certain walls and slope revetment on the south side of the canal. and the removal of the old structures within the limits of the proposed enlargement. On Narch 1 , 1899, a further modfication of some of the detall. of the project was considered by a board of engineers, and their recomendations approved by the chief of Engineere April 8, 1899. These later modifications, together with the work outlined in the report approved January 31, 1890, constituted the existing project toward the completion of which operations were directed. The totals of estimates under the original project and the several revisions are as f0110\%8:

Project of 1883, p. 1539, Annual Report of the Chief of Engineers for $1883 \ldots \ldots \ldots \ldots \ldots \ldots \ldots \ldots \ldots \$ 1,336,363.00$

Revision approved Jenues 31,1890, p. 2217, Annual Report of the Chief of Englueers, 1890........ $710,230.40$

Modification approved April 8 , 1899 , p. 2562, Annual Report of the Chief of Engineers, 1899.... $300,391.98$ A revision of the latter estimate was made November 13, 1900, approved by the Chief of Angineers rovember 17, 1900, and emounted to. 398,359.12 
The Indiana Chute is the main channel of the river by which commerce passes over the fallo when the stage of water is such as to permit narigation via that route. Originalig it was very crooked, with swift currents and whirls, filled with dangerous rocky points projecting from the sides and bottom, and it could be navigated only at stages of eleven feet or more, upper canal gauge. Fren at such stages, the services of special skilled pllots of long experience and having intimate knowledge of the channel conditions were essential for reasonably safe passage through it.

Prior to January 31, 1890, there was no specific comprehengive project for the systematio 1mprovement of the Indiane Chute Channel, although much work, consisting of the removal of some of the more dangerous rock ledges, had been done under estimates and allotments from appropriations for improving the ohio River. on the date mentioned above, the profect submitted by a board of Engineer officere for the radical 1mprovement of this chute was approved by the Chief of Engineers. This project had for its object the widening and deepening of the channel by rock excavation, and the control of water flow by 
means of dikes, etc., so as to make the channel available for descending navigation drawing six and one-half feet at stages of eight feet, upper canal gauge.

A consolidation of the projects for the enlargement at the head of the canal and the Improvement of the Indiana Chute was anthorized by the Chlef of Engineers June 28, 1897, and after that date funda were appropriated for work at both 10celities under one title of appropriation. Work under the project of 1890 having been completed, a board of Angineer officers was aseombled to determine what further work was essential to provide the requisite depth necessary to facilitate the passage of traffio through the channel. This report was submitted December 16 , 1901. The items of additional work found to be necessery to produce the desired result and the estimated cost thereof was as follows:

Submerged Dam at Whirlpool Point (1arge stone), 2,500 yards at \$3... Raising movabio dam north of

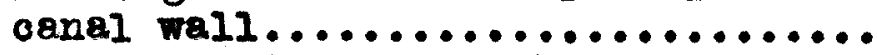
Remoring old dam and building morable dam, 1,000 feet at $\$ 75 \ldots . . . . . .$. . 


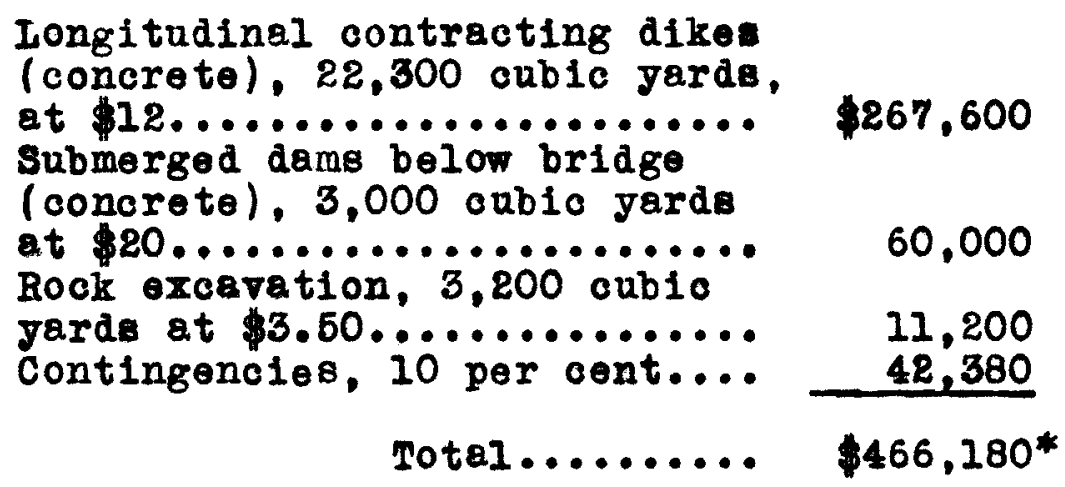

For this latter work the board prescribed the order in which it should be done, and stated that it was possible that a part of the work might become unnecessary if certain results were producod by the submerged dam at Whirlpool point, and in that orent about $\$ 125,000$ would probably be ared from the estimated cost.

Subsequently, in House Document No. 492 , sixtieth Congress, first session, the ohio River board recomended the omission of all of the foregoing items, except that for removing the old dam and building a movable dam at the head of the falls, and in lieu of such omitted items proposed the following to increase the facilitios for passing the falle:

(1) To widen the narrow portion of the canal to 170 foot, thus permitting the passage of a down-bound tow of loaded coal boats and an 
up-bound tow of empty coal boats, each tor three abreast; (2) to construct a new single-lift concrete look south of and by the side of the present lock, available dimensions of the chamber to be 85 feet by 600 feet, thus permitting the passage at one lockage of nine coal boats or twelve coal barges; (3) to create a pool above the falls, with eleration of pool surface at 412.004 (nine feet on upper canal gauge), by the replacing of the wooden dam between Middle and Indiane chutes by a Boule Dam, with crest at 4l2.004, which work is already provided for and under way, and by the construction of sections of dam recomended by the district engineer officer in the project approved by the Chief of Engineers on December 28, 1903, with crests at 412.004 Instead of 411.004, recomended therein, this height of crest being desirable for either a six-foot or a nine-foot slack-water narigation, or eren if the river is not further improved by the slack-water mothod; (4) to remove the rock necessery to complete the widening of the basin at the head of the canal contemplated by the present approved project; (5) to reconstruct the three sections of Boule Dam just north of the head of the canal with crest at 415.704, instead of crest at 412.504, as provided for in present project, thus eliminating the cross current acrose the head of the canal, which current now makes it very difficult for tows to enter the canal at stages between 8 and 12.7 feet. It is proposed to leave the crest of the present fixed concrete dam at 411.404 to serve as fixed weir for low-water discharge of the river. ${ }^{1}$

All elevation are in foet above mean tide at sandy Hook, New Jersey. The estimated cost of the work proposed by this board was as follows:

1. Report of the Chief of Engineers, 1912, p. 932. 
Widening cansl to 170 feet, etc...\$673,000 New locks and eppurtenances...... 773,000 Now Dams.................... 240,000 Reconstructing Boule Dam at head of canal.................... 31,000 Removal of rock in basin........ 43,000

Total........\$1, \$60,000

The river and harbor act of June 25, 1910, adopted a canaliation project for the entire river in accordance with the report printed in House Dooument No. 492, Sixtieth Congress, first session, "or ouch modifications thereof as, in the discretion of the Secretary of War, may be advisablo." This project included the canal widening and new lock (1tems one and two of above estimate).

In order that the Iook and Dam at Louisvilie (110. 4I), might be of the same dimensions as the other looks and dams on the Ohio River, and in order that future navigation might be adequately provided for, the Secretary of War on March 24, 1911, exercised the authority granted him by the act of June 25, 1910 , and approved a modification of the existing profect by inoreasing the canal prism from 170 feet to 200 feet, and by increasing the width of the new lock from 85 feet to 110 feet, at an increase in cost of $\$ 431,500$. As approved in 1912, the existing project 
proposed: (I) to widen the nerrow portion of the canal to 200 feet; (2) construct a now single-lift conorete lock south of and by the side of the present lock, available dimensions to be 110 feet by 600 feet; (3) remove certain rook from basin at head of canal; and (4) create a pool above the falls, with elevation of pool surface at 412.004 (nine feet on upper canal gauge), by the reconstruotion of old sections and building now sections of dam where none previously existed.

The estimate for this work was itemized

as follows:

Tidening the canal to 200 feet etc....\$936,031

Hew lock and appurtenancer..........1,710,325

New Dams and reconstructing Boule

Dam at head of canal............... 271,000

Removal of rocks in basin.......... 43,000

Totel.......\$2,960,356

The act of March 2, 1907 provided for the completion of the third and fourth items and the work has been done, thus leaving only the first and second 1tems as the remainder of the existing project to be completed, for which the estimate emounts to $\$ 2,646,356.1$

The result derived from the expenditures up to 1912 were of marked advantage to traffic and commerce, 
and greatly facilitated their movement. The enlargement of the basin immediately above the locks, oompleted in 1893, increased the width of the canal at that locality from 90 feet to 215 feet throughout a distence of 800 feet. The enlargement at the head of the canal, completed during the fiscal year 1910, begins at a point 725 feet below the Fourteenth street railroad bridge and extends eastwardly to a short distance above the dam, and affords a capacious basin varying in width from 210 foet to 1,200 feet.

In the Indiana Chute above the Fourteenth street bridge the channel width was increased from 200 to 400 feet, and all rock within these limits excarated to grades specified in the project. At Were Rock and Willow Point, all excarations and the dikes were completed. The depth of water over Wave Rock and Willow point approximated very closely the depth anticipated, 1.e., 8 feet when there are 8 feet on the upper gauge. The new dam in 1912 was of such height 8 to afford a minimum depth of nine feot upstream to Madison, Indiana, and a minimum depth of six feet on the lower mitre 811 at lock No. 1 , Kentucky River. 
The following table showe the amount of traffio going through the Iouisville and Portland Canal from 1880 to $1913:^{1}$

\begin{tabular}{|c|c|c|c|c|}
\hline Year & $\begin{array}{l}\text { Passenger } \\
\text { boats }\end{array}$ & $\begin{array}{l}\text { Tow } \\
\text { boats }\end{array}$ & $\begin{array}{l}\text { Coal boats } \\
\text { and barges }\end{array}$ & $\begin{array}{l}\text { Miscel- } \\
\text { Ianoous }\end{array}$ \\
\hline $\begin{array}{l}1880 \\
1881 \\
1888 \\
1883 \\
1884 \\
1885 \\
1886 \\
1887 \\
1888 \\
1889 \\
1890 \\
1891 \\
1892 \\
1893 \\
1894 \\
1895 \\
1896 \\
1897 \\
1898 \\
1899 \\
1900 \\
1901 \\
1902 \\
1903 \\
1904 \\
1905 \\
1906 \\
1907 \\
1908 \\
1909 \\
1910 \\
1911 \\
1918\end{array}$ & $\begin{array}{r}862 \\
1,088 \\
617 \\
1,069 \\
754 \\
748 \\
774 \\
700 \\
850 \\
1,076 \\
504 \\
590 \\
605 \\
573 \\
744 \\
628 \\
650 \\
675 \\
587 \\
562 \\
694 \\
613 \\
600 \\
507 \\
519 \\
410 \\
501 \\
415 \\
338 \\
258 \\
358 \\
565 \\
405\end{array}$ & $\begin{array}{r}235 \\
407 \\
610 \\
769 \\
645 \\
772 \\
856 \\
847 \\
937 \\
767 \\
629 \\
836 \\
1,008 \\
786 \\
871 \\
536 \\
758 \\
732 \\
879 \\
854 \\
988 \\
948 \\
788 \\
863 \\
900 \\
894 \\
1,055 \\
880 \\
1,048 \\
1,014 \\
948 \\
1,244 \\
1,037\end{array}$ & $\begin{array}{l}2,205 \\
2,559 \\
2,545 \\
2,784 \\
2,663 \\
3,086 \\
3,016 \\
2,904 \\
3,293 \\
4,632 \\
2,395 \\
3,197 \\
4,065 \\
1,926 \\
3,635 \\
2,124 \\
2,930 \\
2,658 \\
2,851 \\
2,799 \\
3,256 \\
3,287 \\
2,463 \\
3,052 \\
3,435 \\
2,673 \\
3,599 \\
3,446 \\
3,406 \\
2,809 \\
2,334 \\
2,890 \\
2,789\end{array}$ & $\begin{array}{l}416 \\
142 \\
192 \\
329 \\
284 \\
386 \\
414 \\
318 \\
391 \\
363 \\
412 \\
254 \\
352 \\
499 \\
603 \\
673 \\
631 \\
641 \\
726 \\
873 \\
785 \\
733 \\
891 \\
657 \\
646 \\
750 \\
666 \\
601 \\
377 \\
571 \\
689 \\
632 \\
603\end{array}$ \\
\hline
\end{tabular}

1. Dete obtained from Engineors Reports for corresponding jears. 
The contract for the widening of the Louisilile and portland canal to 200 feet, as authorized in 1912, was completed May 31, 1917. The work of constructing a new lock and widening the canal on the south side near the head of the lock was continued by contract throughout the year of 1917 , and about 86.8 per cont of this contract was completed at the close of the fiscal year. ${ }^{1}$

Under the discretionary authority given to the Secretary of War in the act of 1910 , further modification was made in July, 1925, when It was planned to omit Iock and Dam No. 40, through the rebuilding of the Dem at Loulovilie, (No. 41), as a power-navigation dam, and adjusting the lift to provide the required depth in the river up to Dem No. 39.

Consequently, work was begun on the new dam in September, 1925, ${ }^{2}$ and completed in 1927. 4 it stands to-day, it is the longest and highest navigable dam on the Ohio River. With a crest elevation of 420.0 feet it provides slackwater with a project depth of nine feet between Iouisillile and Dam No. 39

1. Annual Report of the Chlef of Engineers, 1917, p.1253. 2. Ib1a., I926, p. 1158 . 
at Markland Indiana, a distance of about seventy-five milea. The dam which it replacod had a crest elevation of 412.0 feet. This inorease in pool level rendered unnecessary the construction of proposed Dam No. 40 near Madison, Indiana, The cost of constructing the dam was $\$ 2,550,000$. The present Loulsville and Portland Canal. which carries navigation around the dam oxcept during high water stages, has a length of two and one-geventh miles including the locks and lower entrance. The entrence width to the canel is 400 feet, which reduces to 200 feet in the canal proper. Near the head of the locks it again widens to about 600 feet to include 100 foot wide by 235 foot long dry dock, coaling harbor, etc. The minimum depth is serenteen feet. During winter monthe when ice conditions make it necessary for boats to seek refuge, the canal becomes an excellent ice harbor.

The two navigation locks at the lower end of the cenel are the highest lift locks on the ohio River. Both locks have a normal lift of thirty-seven foet and a maximum lift of forty-two feot. The main look wae completed in 1921 at a cost of about $\$ 3,050,000$ which 
Inclades widening of the oanal. This lock is 110 feet by 600 feet, standard Ohio River size. The auxiliary look is fifty-8ix feet by 360 feet and was completed in 1930 at a cost of approximately $\$ 950,000$.

Traffic through Lock and Dam No. 41, at Iouisvilie, emounted to $1,300,000$ tons in 1932 and has shown a steady increase since. In 1937 the amount of traffic was $2,375,000$ tons. 1 The rebuilding of the dam at Iouisville, and the consequent raising of the level of the water in the upper river, caused the government a great deal of trouble in the form of lawsuite by land owners on the river who olaimed property damage resulting from the rising water. Iarge sums of money have been paid out by the government, and several cases are still in the process of litigation. The history of the Louisville and Portland canal would not be complete without some mention being made of the hydro-electrio plant, work on which was begun in May, 1926. The plant was bullt under license of the Federal Power Comission and is owned

1. Mavigation Improvements at Loulspille, Kentucky, pamphlet prepared by the corps of Eng ineers. O.S. Army, 1938, p. 4. 
by the Iouisville Gas and Electric Company. In addition to the usual annual charges made by the United States for the administration of "The Federal Tater Power Act" an annual oharge of $\$ 96,000$ is mado to recompense the United States for "the ase of the Government dam and other structures and the lande adfoining and pertaining thereto owned by the United Stater.n

The water supply for the plan comes from - 91,000 square mile drainage area extending well into New York, Pennsylrania, Virginia, and Margland. The netural flow of the river varies from a maximum of about $1,100,000$ second feet to about 5,000 second feet or less in summer drought. The dam, together with the natural fall of some twenty-six feet in the river bed at the falls, provides a maximum operating head of about thirty-seven feet. At present eight 13,500 h.p. units are installed and provision is made for two additional unita. Because of their ability to operate under heads varying from the maximum of thirtyeseren feet down to about eight feet, five blade type, axial-flow runners, designed to produce 13,500 h.p. at thirty-8even foot net effective head at a speed of 100 revolutions per minate, were 
selected.

The hydro-plant is a strictly run-of-theriver plant and no drawdown of the navigation pool of Dam No. 41 is permitted. Consequently low flows result in a curtallment of power output. Also due to high water stages and the resulting reduction in operating head to below eight feet, the plant has been unable to operate for an average of about thirtyf1ve deys each jear.

Since the hydro-electric plant was put into operation the latter part of 1987 , it has produced an average of $290,000,000 \mathrm{~K} \cdot \mathrm{H} \cdot \mathrm{H}$. per year. The average annual output during 1931 to 1935 inclusive was about $338,000,000 \mathrm{~K} \cdot \mathrm{W} \cdot \mathrm{H}$. The meximum output in ang single year was $392,957,000 \mathrm{~K} \cdot \mathrm{W} \cdot \mathrm{H}$. in 1931 .

The cost of constructing the power plant, incluaing all equipment, the transmission line to the waterside steam station of the Iouisville Gas and Electric Company, and the substation at the plant, was about $\$ 8,100,000$. This represents. a oost of $\$ 75.00$ per h.p., or about $\$ 100.00$ per installed KT. The comparatively low cost per kilowatt of installed capaoity made the building of the plant, the output of which is entirely secondary power, financially 
practicable.

The damaging flood of January 1937 which took such an enormous property toll in and around the city of Loulsville, oddly enough caused very little injury to the canal proper. Although the peak of the flood waters stood well above the walls of the canal, very little mud or silt was deposited by the receding waters. The only damage done to the canal property was the destruction of a fow old buildings which had already outlived their usefulness. 2

This study of the orlgins and history of the Louisville and Portland Canal, contains several points of importance to the student of Amerioan history. It shows the intense interest of the people of the West in internal 1mprovements. The cost wes three times the estimate, which is typioal of many of the governmentel enterprises of the period. The people were very anxious to get men to invest their money in the undertaking, but when dividends which the legislature of Kentucky had authorized becamo

1. Navigation Improvements at Louigville, Kentuory, op. cit., pp. 9-10.

2. This information was obtained from conferences with employeer of the United States District Engineers office at Louisville. 
a reality, the demand became urgent that the National government take over the canal, and lower the tolls or grant free passage. The votes in the Senate of Kentucky, and in the branches of the United States Congress indicate a sectional interest, which is also typical throughout our history. 1

Governor Desha wished the state of Kentucky to construct the canal and to use the profits to build turnpikes etc., and to use the profits of all internal improvements, to maintain these works and to further the development of liberal institutions. The shattering of his dream must heve caused him much distress. The United States, by taking charge of the canal, extended its power one step further over the waterways of the nation. It was an institution out of which the government made a huge profit as a stockholder, but as sole owner mede less than nothing.

4. Ikeable object of comparison is furnished by the Erie Canal, which was completed in 1825, just five years previous to the opening of the Iouistille

1. Walker, H. P., Indiana Magazine of History, V. 28. 
and Portland profect. There are several important differences between the two, and a few similarities which might be considered here. Both canals were constructed with the ides of improving and increasing the trade of a growing young nation, not only betweon Eastern and Western United States, but also with other nations of the rorld, and both successfully fulfilled their purpose.

The same difficulties which beset the incorporators of the Louisville and Portland canal Company also harassed De Witt Clinton and his colleagues who foresaw the benefits of bringing ships from Iondon and other ports of Europe through the Hudson River to Lake Erie by means of a canal. Both experienced obstacles in enlisting financial assistance, and the construction and improvement of each was hindered by a major war.

Each canal had to go through a series of enlargements in order to keep pace with the adrances made in the typer of commercial ressels, and each, at one time or enother proved to be profitable husiness ventures.

The cost of the Erie Canal exceeded the estimate by over $\$ 2,000,000$, and the same fact in 
different amount was true of the Louisville and Portland canal. Both, however, compensated for their extre expense by the great value they rendered to the economic progress of the United State8.

One great difference which must seem obvious in a comparison of these two great works is the fact that the Erie Canal was begun and completed as public enterprise by the State of New York, while the Louigville and Portland Canal, as we have seen, was started under privete initiative and wound up under the control of the United states Government.

Another difference between the two projects which immeditely comes to the mind of one who has studied the respective development of each, is the fact that while the Erie Canel was used more or lesa a日 a "political footbali" by the various public officeholders of New York, no trace of eny such manoeuvering was found by the writer concerning the construction and management of the canal which is the subject of this paper. Furthermore, it seeme appropriate here to commend those private stockholders who having only the interest of fire shares of stock in the 
company, so ably and honorably carried on its burdensome affairs as trustees of a negligent government.

The leaders of both projects found it expedient to go to the National Government for monetary aid. In the case of one, it was refused due to the burdens of the war of 1812. In the case of the other, financial assistance was given, due perhaps to the fact that the request came at a time when the Treasury of the United States was showing a surplus, and when those in control of the government realized the benefits to be obtained in later years from the early construction of internal improvemente. 


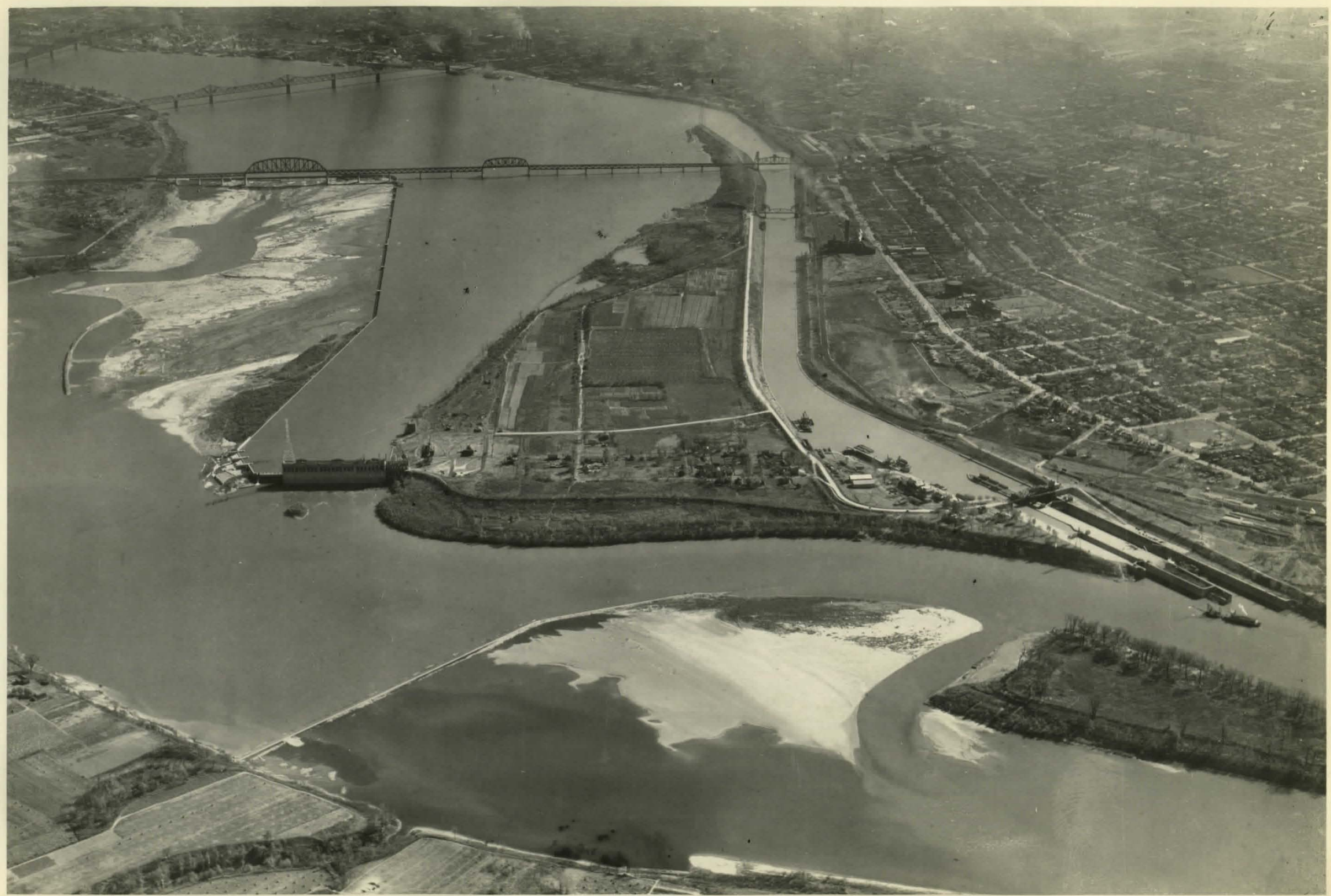

WAR DEPAPTIMENT

U. S. ENGINEER OFFICE

LOUISVILIE DISTRICT

F1le 32 
BIBIIOGRAPHY 
BIBIIOGRAPHY

Original Source Materiale:

1. Annuel Reports of the President and Directors of the Louisvilie and Portland canal to the Iegisiature of Kentuck

2. Innual Reporte of the United States Army Chief of Engineers to the Secretary of Far, 1868 to 1938 .

3. Senate Journals of the State of Kentucky, 1824 to 1870 .

4. Iittell, Wm., Statute Iaw of Kentucky, Vols. I-III. Kendell and RuseriI, Frankfort, Kentucky, 1822.

5. Statutes of Kentucky, 1805 to 1872. (Containing the Acts of the leglelature of the state of Kentuekg.)

6. Proceedings of the Managers of the ohio Canal Company, Printed by Daniel Bradford, Iexington, 1805 .

7. Laws of the United States, Relating to the Improvement of Rivers and Harbors, VoIs., I and II.

8. Kentuoky Documents, 1825-1872.

9. Charter, By-18w8 etce, of the Louispille and Portiand Canal Company, Printed by S1 Penn Jr. Lou187iIle, 1825 .

10. Report of the Secretary of War, 28th Congress, Ist Session.

11. Executive Document, No. 42, H. of R. 32nd Congress, 2nd Session. 
12. Bxecutive Document, No. 74, H. of R. 34th Congress, 18t Session.

13. Executive Document, No. 131, H. of R. 35th Congress, 18t session.

14. Executive Document No. 83, H. of R. 40th Congres8, 2nd Session.

15. Executive Document No. 17, U. S. Senate, 46 th Congress, 3rd session.

16. Execut1ve Dooument Ho. 348, H. of R. 46th Congress, 2nd session.

17. Executive Document No. 129, U. S. Senate, 47th Congress, lst session.

18. Executive Document No. 51, H. of R. 49th Congress, 2nd session.

19. Executive Document 10. 492, H. of $R$. 60th Congress, lst session.

20. Executive Document No. 1139, H. of R. 62nd Congre86, 3ra session.

21. Executive Document No. 1659, H. of R. 64th congres8, and session.

22. American State paperg; documents, legislative and executive of the congress of the United states, Washington, Gales and Co., 1832-1861.

23. Register of Debates in Congress. Congressional Globe, Congressionel he cord, Government Printing Office, Tth ed., Washington, 1918.

24. Conferences with United States Engineers, Federal Building, Louisville, Kentucky. 
Secondary Materials:

1. Ball, W. J., Indiana Canal Company, Printed by $\mathrm{E}$. Shepard, CincInnat1, 0h10, 1850.

2. Bernhard, Karl, Trevele Through North Amorica, Vol. II, 1828.

3. Collins, Lewis, History of Kentuoky, (Revised by Richard H. CoIIIng), Vol. I, John P. Morton Co., Ioulsville, 1924.

4. Connelley, W. E., and Coulter, E. M. History of Kentucky, Vol. I, The morican History Society, Chicago, 1922.

5. Faulkner, H. U., Economic History of the United States. The Macmillan Company, New York, 1928.

6. Hepburn, A. B. , Artificial Waterways and Commerciel Development, The Macmilian Company

7. Hulbert, A. B., Historic Highways, Vols. 13 and 14, Arthur H. Clark \& Company, Cleveland, 1904 .

8. Hulbert, A. B., Pllots of the Republic, A. C. McClurg \& Company, Chioago, 1906.

9. Johnston, J. S., Memorial History of Loulsville, V01. I, American Blographical Publishing company, 1896.

10. Peyton, J. H. , American Transportation Problem, Courier Journel Job Printing Compeny, Ioulsvilie, 1908 .

11. Wilson, S. M., History of Kentucky, VoI. II, S. J. Clarke Publishing Company, Chicego and Louigville, 1928. 


\section{Poriodicals:}

1. F1lson Club History Querterly, Vols., IV and VI, Pabilshed Quarterly by the Filson Club, Iouisville, Kentucky.

2. Indiana Magazine of History, Vol. 28, Department of History, Indiana University. Bloomington, Indiane, 1932.

3. Louisville Board of Trade Journal, Published by the Iouleville Board of Irade, May, 1926. 